\title{
Local sources of global climate forcing from different categories of land use activities
}

\author{
D. S. Ward ${ }^{1,2}$ and N. M. Mahowald ${ }^{2}$ \\ ${ }^{1}$ Atmospheric and Oceanic Sciences, Princeton University, Princeton, New Jersey, USA \\ ${ }^{2}$ Department of Earth and Atmospheric Sciences, Cornell University, Ithaca, New York, USA \\ Correspondence to: D. S. Ward (dsward@princeton.edu)
}

Received: 22 October 2014 - Published in Earth Syst. Dynam. Discuss.: 17 December 2014

Revised: 25 March 2015 - Accepted: 26 March 2015 - Published: 15 April 2015

\begin{abstract}
Identifying and quantifying the sources of climate impacts from land use and land cover change (LULCC) is necessary to optimize policies regarding LULCC for climate change mitigation. These climate impacts are typically defined relative to emissions of $\mathrm{CO}_{2}$, or sometimes emissions of other long-lived greenhouse gases. Here we use previously published estimates of the radiative forcing (RF) of LULCC that include the short-lived forcing agents $\mathrm{O}_{3}$ and aerosols, in addition to long-lived greenhouse gases and land albedo change, for six projections of LULCC as a metric for quantifying climate impacts. The LULCC RF is attributed to three categories of LULCC activities: direct modifications to land cover, agriculture, and wildfire response, and sources of the forcing are ascribed to individual grid points for each sector. Results for the year 2010 show substantial positive forcings from the direct modifications and agriculture sectors, particularly from south and southeast Asia, and a smaller magnitude negative forcing response from wildfires. The spatial distribution of future sources of LULCC RF is highly scenario-dependent, but we show that future forest area change can be used as a predictor of the future RF from direct modification activities, especially in the tropics, suggesting that deforestation-prevention policies that value land based on its C-content may be particularly effective at mitigating climate forcing originating in the tropics from this sector. However, the response of wildfire RF to tropical land cover changes is not as easily scalable and yet imposes a non-trivial feedback onto the total LULCC RF.
\end{abstract}

\section{Introduction}

Global land use and land cover change (LULCC) is recognized as an important element of past and future anthropogenic climate changes (Feddema et al., 2005; van der Werf and Peterson, 2009; Foley et al., 2011). Decision makers are faced with the major challenge of meeting increasing global demands for food products (Godfray et al., 2010) while simultaneously minimizing the climate costs of expanding or intensifying agriculture. The Reducing Emissions from Deforestation and Forest Degradation (REDD) program is a one such effort that seeks to lower anthropogenic greenhouse gas emissions from deforestation using financial incentives to maintain or increase forest area (Lubowski and Rose, 2013).

Estimating the costs to climate from LULCC activities is necessary for developing policies like REDD, yet these costs are difficult to define. The total $\mathrm{CO}_{2}$ emitted is sometimes used for this purpose (e.g. Mendelsohn and Dinar, 2009), or global warming potentials and $\mathrm{CO}_{2}$ equivalents are used to include the effects of other long-lived greenhouse gases (e.g. van der Werf and Peterson, 2009; Cherubini et al., 2012; Reisinger and Ledgard, 2013). However, changes in forest area also modify the land surface biophysics (such as albedo) and emissions of short-lived species: aerosols and precursors to ozone formation. Several studies have shown that when other forcing agents besides $\mathrm{CO}_{2}$ are considered, the contribution of LULCC to global climate change can be highly dependent on the location of the LULCC (Claussen et al., 2001; Brovkin et al., 2004; Bala et al., 2007). For example, clear-cutting of extra-tropical forest emits $\mathrm{CO}_{2}$ but also reveals the land surface underlying the forest canopy that, when snow-covered, is highly reflective. The cooling impact of the albedo change can compensate for the warming of the 
emitted $\mathrm{CO}_{2}$, and has even been shown to dominate at high latitudes (Claussen et al., 2001; Matthews et al., 2004). Patterns of wildfire activity also change as a result of land management (Houghton et al., 1999; Kloster et al., 2012), with feedbacks onto the global carbon cycle, and emissions of carbonaceous aerosols and trace gases. Finally, the impacts of LULCC include agricultural activities that often follow deforestation (Foley et al., 2005) and lead to emissions of $\mathrm{CH}_{4}$, $\mathrm{N}_{2} \mathrm{O}, \mathrm{NH}_{3}, \mathrm{NO}_{x}$, and dust (Ward et al., 2014; Ginoux et al., 2012).

The general approach to identifying sources of anthropogenic impacts on climate has been to divide the impacts by the forcing agent (e.g. Forster et al., 2007; Myhre et al., 2013). However, as pointed out by Unger et al. (2010), it is more useful for policy making to break impacts down into contributions by economic sectors. Specific sectors can be regulated more easily than an individual forcing agent, such as $\mathrm{CH}_{4}$, that has many sources both from industry and from land use. Given the large role of LULCC in presentday anthropogenic climate forcing (Ward et al., 2014), there is a need to know what activities are driving this forcing and to address whether the majority of climate forcing from LULCC activities results from deforestation, agricultural emissions, or from wildfire feedbacks. Further questions regarding where contributions from LULCC to climate change originate geographically are important on countrylevel and smaller scales for assessments of individual country responsibilities for climate change and potential for mitigation (Elzen et al., 2013; Matthews et al., 2014).

In this study, we use previously compiled estimates of the global LULCC radiative forcing (Ward et al., 2014) for six future scenarios, including the four representative concentration pathways (RCPs; Moss et al., 2010), and compute the contributions of three major LULCC sectors to the total radiative forcing (RF): agriculture, direct modifications to the land surface (e.g. deforestation, reforestation, wood harvesting), and the wildfire feedback. The first of the two non-RCP scenarios projects business-as-usual deforestation activity in the tropics through year 2100 and the second is a theoretical extreme case in which all arable and pasturable land is cultivated or converted to pasture by the year 2100 . The extreme case is intended to be a worst-case scenario that is not likely to be realized but is instructive as an upper bound of LULCC impacts. These pessimistic scenarios are added to expand the range of projected future land use because the RCP scenarios are optimistic in their estimates of current and future land use conversion compared to current census- and satellitebased estimates (see Fig. 5 in Ward et al., 2014; FAO, 2010; Hansen et al., 2013; Kim et al., 2015). The global total and sector-specific forcings are ascribed to their source locations on a latitude/longitude grid basis for historical LULCC and for the projected LULCC of the future scenarios. With these methods, our objectives are to (1) identify where the RF of specific LULCC activities will likely come from in the future, and, based on this information, (2) to assess the relative importance of land use location and type of activity for future mitigation of global RF.

\section{Methods}

The methodology employed in this study is explained in this section in four steps. First, a brief summary is given of the computation of global RFs due to LULCC from Ward et al. (2014) that are used in this study (Sect. 2.1) with additional details given in Appendix A. This is followed by a description of the future LULCC scenarios used by Ward et al. (2014) and in this study, and also the development of an additional scenario (Sect. 2.2). In Sect. 2.3, the methods for attributing the global LULCC RFs for each scenario to three major sectors of land use activities are explained, supplemented by Appendix B. Finally, our approach for ascribing the sector and agent-specific RFs to individual source locations is described in Sect. 2.4.

\subsection{Use and calculation of global RFs}

We use the adjusted radiative forcing (RF), as defined by Forster et al. (2007), and relative to a preindustrial state (year 1850), to measure the impacts of LULCC activities. RF has several advantages as a metric for this kind of study in which different forcing agents are assessed together. The RF is defined the same way for short-lived and long-lived forcing agents allowing for their direct comparison. Also, this metric has been used in many studies, including the Intergovernmental Panel on Climate Change assessment reports, to compute the total anthropogenic contribution to climate change, providing substantial context within which to place our results (Forster et al., 2007; Myhre et al., 2013).

It has been demonstrated that the biophysical effects of LULCC have a different climate sensitivity compared to identical forcing from $\mathrm{CO}_{2}$ (e.g. Davin et al., 2007; Pongratz et al., 2008), and that the biochemical and biophysical RFs of LULCC are not strictly additive when it comes to surface temperature response (Jones et al., 2013). However, estimates of the efficacy of LULCC biophysical effects, which account for varying climate responses among forcing agents, range from 0.3 to 5 depending on model assumptions (Hansen et al., 2005; Davin et al., 2007; Cherubini et al., 2012) and, being defined by the global climate response, may not apply equally to specific source locations. Therefore we adopt RF as an assessment metric and acknowledge the uncertainty regarding the climate response to the different forcing agents, and the limits of the RF concept for predicting the diverse climate impacts of land use (Betts, 2008; Runyan et al., 2012). Pongratz and Caldeira (2012) show that preindustrial LULCC, which we do not consider in our study, accounts for less than $10 \%$ of historical anthropogenic climate change (measured as global surface temperature change), but can alter the proportional contributions of individual countries to climate change in important ways. They find that in- 
cluding preindustrial LULCC emissions enhances the contribution of developing countries, particularly in south Asia, however we are not able to capture this enhancement in our study.

The RFs attributed to LULCC by Ward et al. (2014) from changes to greenhouse gas concentrations, including $\mathrm{CO}_{2}$, $\mathrm{N}_{2} \mathrm{O}, \mathrm{CH}_{4}$, and $\mathrm{O}_{3}$, aerosol direct and indirect effects, including biogeochemical feedbacks, and surface albedo, are used in this study. Their analysis includes deforestation, afforestation and other land cover changes, deforestation fires, wood harvesting, agricultural emissions from livestock, fertilizer and waste burning, and changes to wildfires caused by land cover change. They compute uncertainties for the RF from each forcing agent and find that LULCC account for $40 \pm 16 \%$ of year 2010 anthropogenic RF by a combination of substantial positive forcing from non- $\mathrm{CO}_{2}$ greenhouse gases and the absence of major negative forcing from aerosols. The forcings calculated by Ward et al. (2014) are within the uncertainty ranges for estimates of the total anthropogenic RF published in major assessments (e.g. Myhre et al., 2013; Vuuren et al., 2011), suggesting that different approaches would likely achieve similar results. Carbon emissions from soils that are managed or disturbed by anthropogenic activities (Lal, 2004) were not included in this analysis. Forcing from changes to evapotranspiration, sensible heat flux, and associated changes to cloud cover (Molen et al., 2011) are difficult to define with the RF metric and are excluded from the Ward et al. (2014) calculations. They also did not consider changes to fluvial $\mathrm{C}$ fluxes (Moore et al., 2013), changes to natural $\mathrm{CH}_{4}$ and $\mathrm{N}_{2} \mathrm{O}$ emissions from LULCC (Lehner and Doll, 2004), or irrigation (Boucher et al., 2004). Direct radiative effects of nitrate aerosols were not included. Nitrate aerosol concentrations can be enhanced by emissions from fertilizer and livestock and act to reduce the RF from these agricultural sectors by increasing scattering of solar radiation (Unger et al., 2010). Future RFs were computed against a background of non-LULCC anthropogenic emissions following RCP4.5 (Wise et al., 2009). A more detailed summary of the methodology of Ward et al. (2014) is given in Appendix A.

\subsection{Future scenarios}

RFs were estimated by Ward et al. (2014) for the year 2100 (relative to 1850) given historical LULCC (Hurtt et al., 2011) and five projections of future LULCC including four developed as part of the Coupled Model Intercomparison Project phase 5 (CMIP5) (Taylor et al., 2012) corresponding to each of the four representative concentration pathways (RCP2.6, RCP4.5, RCP6.0, RCP8.5) (Hurtt et al., 2011; Lawrence et al., 2012). The fifth projection represents a theoretical extreme case (TEC) in which all arable land is converted to crops at a linear rate between years 2010 and 2100, and remaining pasturable land (defined as land for which the climate would support crops but where the soil is too nutrient- poor) is converted to grasses (Ward et al., 2014). The TEC leads to a near complete deforestation of the tropics and more than 2.5 times the present-day crop area. Since the land use included in the RCPs is thought to be smaller than is likely in reality based on historical land use change (e.g. Ward et al., 2014), the TEC allows us to have a higher-than-likely estimate in order to bound the probable impacts of land use on climate.

All projections represent LULCC as changes in plant functional type (PFT) coverage over time, with redistribution of carbon by wood harvesting also included (Lawrence et al., 2012). Recent work has demonstrated that changing agricultural practices, even something as simple as improving livestock feeding, can also reduce greenhouse gas emissions (Bryan et al., 2012). Here we assume changes in agricultural practices are consistent with the LULCC projections created to accompany the representative concentration pathways.

Forest area projections for all four RCP scenarios assume reductions in the rate of global deforestation during the 21st century (Lawrence et al., 2012). It is also important to understand the impacts of LULCC and the sources of these impacts under a scenario in which current land use practices are continued. To address this knowledge gap we introduce a sixth projection in which tropical forest area changes for years 2010 to 2100 follow the year 2000 to 2010 rates published by the FAO (2010). Together with the RCPs, this creates a more comprehensive range in possible outcomes for the 21 st century. In this tropical business-asusual (Trop-BAU) scenario, the forest area change reported for each country is gridded. Only grid points with past forest area loss were allowed to experience future loss, although in the case of completely deforested grid points the forest loss spilled into adjacent points. Forest PFTs are converted to cropland and pasture (grasses) at proportions of 80 and $20 \%$, respectively, as reported by Houghton (2012) for the tropics. Global wood harvesting rates and extra-tropical land cover changes in the Trop-BAU scenario are from RCP8.5. Some reforestation was reported in southeast Asia between 2000 and 2010 (FAO, 2010), but we assume only tropical forest area loss in Trop-BAU, citing an increase in net forest loss in this region between 2005 and 2010 (FAO, 2010). Recent studies suggest that deforestation rates are higher than reported in census data (Hansen et al., 2013; Margono et al., 2014), especially in the tropics (Kim et al., 2015). Therefore, the Trop-BAU scenario may underestimate global forest area loss if current rates were to continue during this century.

\subsection{Assigning RF to sectors}

We divide RFs attributed to LULCC into three groups of anthropogenic activities and feedbacks (Fig. 1). The first group, direct modifications, includes land cover changes with associated deforestation fires, and wood harvesting. We define land cover changes as the replacement of a biome, such as grassland or forests, with a different biome through anthro- 
pogenic activity. The agricultural emissions group contains $\mathrm{N}_{2} \mathrm{O}$ and $\mathrm{CH}_{4}$ emissions from livestock and fertilizer application, dust emissions from cultivation, and waste burning. It is important to emphasize the distinction we make between fires that are associated with different activities. We include fires associated with the act of deforestation in the direct modifications category, while yearly burning of agricultural waste falls into the agriculture category. Finally, changes in wildfire activity that result from land cover changes comprise the third category.

We take a simple approach to apportioning the global LULCC RF into these three categories. Forcing is assigned to a category in proportion to the fraction of global LULCC emissions of the forcing agent, or agent precursor gases, that are associated with the category. For example, roughly $90 \%$ of LULCC $\mathrm{NO}_{x}$ emissions were from agricultural activities in the year 2010, with the remainder associated with deforestation fires. The same percentage of forcing due to tropospheric $\mathrm{O}_{3}$, roughly $90 \%$, is attributed to the agriculture sector. A global reduction in wildfire emissions from land cover change leads to a $15 \%$ decrease in total LULCC $\mathrm{NO}_{x}$ emissions, and we attribute $15 \%$ of the total LULCC $\mathrm{O}_{3} \mathrm{RF}$ of the opposite sign to the wildfire forcing category. For shortlived species like $\mathrm{O}_{3}$, forcing efficiency (global mean forcing per unit emission) can depend on the location and timing of the emissions (Shindell et al., 2009; Streets et al., 2013). We have defined the three LULCC categories such that, in general, emissions of a particular forcing agent are dominated by one category, which will minimize the errors introduced by this effect on the short-lived forcings. Additional details regarding attributing individual forcing agents to sectors are given in Appendix B.

\subsection{Ascribing RF to the grid}

To ascribe the global RF to each point on a $1.9^{\circ}$ latitude by $2.5^{\circ}$ longitude grid we assume that the contribution to the global RF from a grid point is proportional to its share of the global emissions of the forcing agent in question (or emissions of $\mathrm{NO}_{x}$ for the $\mathrm{O}_{3}$ and indirect $\mathrm{CH}_{4}$ forcings). This assumption holds well for globally well-mixed forcing agents such as $\mathrm{CO}_{2}$. A kilogram of $\mathrm{CO}_{2}$ emitted from the extratropics carries similar weight, in RF terms, as a kilogram of $\mathrm{CO}_{2}$ emitted from the tropics. However, Bowman and Henze (2012) showed that for the short-lived greenhouse gas, $\mathrm{O}_{3}$, tropical emissions lead to an enhanced RF relative to extratropical emissions. This is also potentially important for aerosols, including direct effects, due to latitudinal changes in solar insolation, and indirect effects, due to regional differences in cloud regimes (Chuang et al., 2002). Ward and Mahowald (2014) show that ascribing RF from short-lived forcing agents to individual locations based on proportional emissions is reasonable for comparing the climate impacts of developed countries, as a group, to developing countries. However, on smaller spatial scales, there are likely to be

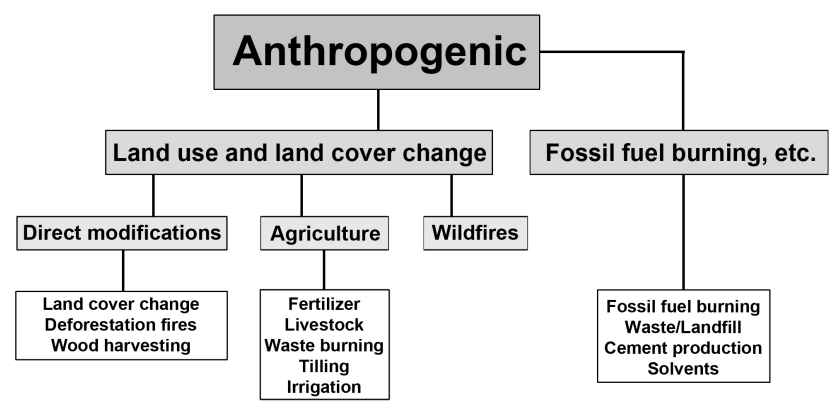

Figure 1. Breakdown of anthropogenic activities into categories associated with land use and land cover change, and fossil fuel burning. Note that "wildfires" refers only to the change in wildfire activity (non-deforestation and non-agricultural fires) that results from anthropogenic land use and land cover change.

differences in the radiative forcing efficiency of short-lived forcing agents, especially aerosols, emitted from different locations (Streets et al., 2013). Here we weight all aerosol emissions equally, regardless of the source location, and note that the aerosol effective radiative forcings (ERFs) attributed to LULCC activities are small compared to other forcings (Ward et al., 2014).

\section{Results}

\subsection{Land use RF by sector}

In the year 2010, the LULCC RF consists of two large positive contributions from direct modifications to the land cover and from agricultural activities, and a smaller negative contribution from changes to wildfire activity (Table 1; Fig. 2). The major source of positive forcing from direct modifications to the land cover is from $\mathrm{CO}_{2}$ emissions, with a minor negative forcing from albedo change and small contributions from aerosols and non- $\mathrm{CO}_{2}$ greenhouse gases. In contrast, forcing from the agriculture sector is comprised mainly of positive forcings from non- $\mathrm{CO}_{2}$ greenhouse gases. These two sectors combined account for more than $1 \mathrm{~W} \mathrm{~m}^{-2}$ of forcing. Global reductions in wildfire activity due to increased land management since the preindustrial time period enhance the terrestrial carbon sink, leading to a negative forcing from this sector (Fig. 2).

The future scenarios show considerable variation in the breakdown of forcing between LULCC sectors (Table 1). The RCP2.6 scenario is characterized by widespread proliferation of biofuel crops, largely at the expense of forests (Vuuren et al., 2007; Hurtt et al., 2011). This storyline is expressed in the RF as high positive forcing from direct modifications to land cover $\left(0.94 \mathrm{~W} \mathrm{~m}^{-2}\right)$, mainly $\mathrm{CO}_{2}$ emissions from deforestation, but only a small contribution from agricultural activities $\left(0.27 \mathrm{~W} \mathrm{~m}^{-2}\right)$. Due to the expansion of crop land in RCP2.6, fertilizer emissions of nitrogencontaining species increases dramatically by the year 2100 . 
Table 1. RF values $\left(\mathrm{W} \mathrm{m}^{-2}\right.$ ) for each sector, direct modifications to land cover (D), agriculture (A), and the wildfire response (W) for year 2010, and for the year 2100 given each of the six future scenarios used in this study.

\begin{tabular}{|c|c|c|c|c|c|c|c|c|c|c|c|c|}
\hline & \multicolumn{3}{|c|}{2010} & \multicolumn{3}{|c|}{ RCP2.6 } & \multicolumn{3}{|c|}{ RCP4.5 } & \multicolumn{3}{|c|}{ RCP6.0 } \\
\hline & A & $\mathrm{D}$ & $\mathrm{W}$ & A & $\mathrm{D}$ & W & A & $\mathrm{D}$ & $\mathrm{W}$ & A & $\mathrm{D}$ & W \\
\hline $\mathrm{CO}_{2}$ & -0.01 & 0.71 & -0.26 & -0.17 & 0.87 & -0.28 & -0.03 & 0.55 & -0.21 & -0.08 & 0.84 & -0.28 \\
\hline $\mathrm{N}_{2} \mathrm{O}$ & 0.14 & 0.00 & 0.00 & 0.26 & 0.00 & 0.00 & 0.18 & 0.00 & 0.00 & 0.22 & 0.00 & 0.00 \\
\hline $\mathrm{CH}_{4}$ & 0.33 & 0.01 & -0.03 & 0.07 & 0.00 & 0.11 & 0.41 & 0.00 & -0.10 & 0.36 & 0.00 & -0.08 \\
\hline $\mathrm{O}_{3}$ & 0.13 & 0.01 & -0.02 & 0.10 & 0.00 & -0.05 & 0.19 & 0.00 & -0.08 & 0.17 & 0.00 & -0.09 \\
\hline Aerosol DRE & 0.01 & -0.01 & 0.00 & 0.01 & 0.09 & -0.10 & 0.01 & 0.04 & -0.05 & 0.01 & 0.07 & -0.07 \\
\hline Aerosol IRE & -0.01 & 0.00 & 0.01 & -0.01 & 0.05 & 0.03 & -0.01 & 0.02 & 0.02 & -0.01 & 0.03 & 0.02 \\
\hline Land albedo & 0.00 & -0.06 & 0.01 & 0.00 & -0.08 & 0.02 & 0.00 & -0.02 & 0.00 & 0.00 & -0.06 & 0.01 \\
\hline Snow albedo & 0.01 & 0.00 & 0.00 & 0.01 & 0.00 & 0.00 & 0.01 & 0.00 & 0.00 & 0.01 & 0.00 & 0.00 \\
\hline \multirow[t]{3}{*}{ TOTAL } & 0.60 & 0.66 & -0.29 & 0.27 & 0.94 & -0.28 & 0.77 & 0.59 & -0.42 & 0.68 & 0.88 & -0.51 \\
\hline & \multicolumn{3}{|c|}{ RCP8.5 } & \multicolumn{3}{|c|}{ Trop-BAU } & \multicolumn{3}{|c|}{ TEC } & & & \\
\hline & A & $\mathrm{D}$ & $\mathrm{W}$ & A & $\mathrm{D}$ & $\mathrm{W}$ & A & $\mathrm{D}$ & $\mathrm{W}$ & & & \\
\hline $\mathrm{CO}_{2}$ & -0.10 & 1.19 & -0.40 & -0.17 & 1.50 & -0.50 & -0.32 & 2.28 & -0.73 & & & \\
\hline $\mathrm{N}_{2} \mathrm{O}$ & 0.25 & 0.00 & 0.00 & 0.27 & 0.00 & 0.00 & 0.41 & 0.00 & 0.00 & & & \\
\hline $\mathrm{CH}_{4}$ & 0.57 & 0.00 & 0.12 & 0.63 & 0.00 & 0.17 & 1.65 & -0.02 & -0.02 & & & \\
\hline $\mathrm{O}_{3}$ & 0.21 & 0.00 & -0.10 & 0.23 & 0.00 & -0.12 & 0.43 & -0.05 & -0.14 & & & \\
\hline Aerosol DRE & 0.02 & 0.10 & -0.13 & 0.01 & 0.19 & -0.18 & 0.03 & 0.34 & -0.14 & & & \\
\hline Aerosol IRE & -0.02 & 0.12 & 0.11 & -0.02 & 0.22 & 0.12 & -0.06 & 0.38 & 0.08 & & & \\
\hline Land albedo & 0.00 & -0.08 & 0.04 & 0.00 & -0.12 & 0.04 & 0.00 & -0.24 & 0.06 & & & \\
\hline Snow albedo & 0.00 & 0.00 & 0.00 & 0.00 & 0.00 & 0.00 & 0.03 & 0.00 & 0.00 & & & \\
\hline TOTAL & 0.93 & 1.33 & -0.38 & 0.95 & 1.78 & -0.47 & 2.15 & 2.69 & -0.90 & & & \\
\hline
\end{tabular}

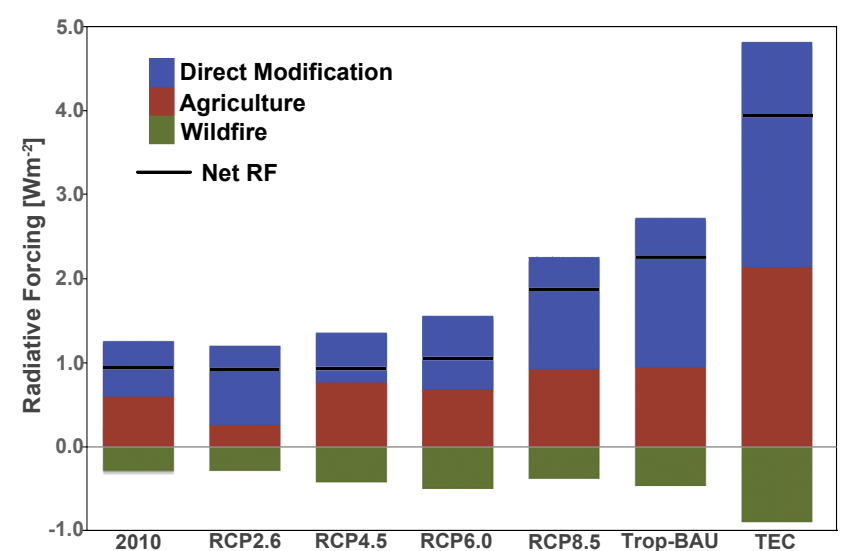

Figure 2. The fraction of radiative forcing from each main sector as defined in Fig. 1. The forcings are reported for the year 2010 (2010) or in year 2100 (RCP2.6, RCP4.5, RCP6.0, RCP8.5, Trop-BAU, TEC).

This leads to a forcing from $\mathrm{N}_{2} \mathrm{O}$ of $0.26 \mathrm{~W} \mathrm{~m}^{-2}$, but also a massive drawdown of $\mathrm{CO}_{2}$ from increased $\mathrm{N}$ deposition, a forcing of $-0.20 \mathrm{~W} \mathrm{~m}^{-2}$ (note the $\mathrm{CO}_{2} \mathrm{RF}$ from agriculture reported in Table 1 also includes a $+0.03 \mathrm{~W} \mathrm{~m}^{-2} \mathrm{RF}$ from the carbon cycle response to the forcing from this sector). Previous studies have also shown that $\mathrm{N}$ emissions from agriculture may have a near-neutral RF because of these compet- ing effects (Zaehle et al., 2011; Ward et al., 2014). Livestock emissions of $\mathrm{CH}_{4}$ in $\mathrm{RCP} 2.6$ decrease from present day to 2100 (Vuuren et al., 2011), so the contribution from methane $\mathrm{RF}$ is small compared to the other scenarios.

While RCP2.6 projects proliferation of biofuels, RCP4.5 includes widespread afforestation in response to a global carbon tax policy. The afforestation is reflected in the RF of direct modifications to land cover for RCP4.5, which is the only scenario that leads to a decrease in the RF from this sector between 2010 and 2100 (Fig. 2). Wildfire emissions of $\mathrm{CO}_{2}$ decrease due to LULCC in RCP4.5, despite the afforestation in this scenario. The decrease in fires results mainly from continued increases in tropical wood harvesting (Lawrence et al., 2012). For the remaining realistic future scenarios, the total RF attributed to LULCC is progressively higher going from the RCP6.0, to the RCP8.5, to the Trop-BAU. The positive contributions to RF from direct modifications and agriculture in the TEC case are similar in magnitude, both above $2 \mathrm{~W} \mathrm{~m}^{-2}$. While the $\mathrm{CO}_{2}$ forcing from direct modifications is large in the TEC $\left(2.28 \mathrm{~W} \mathrm{~m}^{-2}\right)$, the extreme expansion of pasture leads to a contribution from agricultural $\mathrm{CH}_{4}\left(1.65 \mathrm{~W} \mathrm{~m}^{-2}\right)$ that is nearly 3 times the same forcing for RCP8.5 LULCC. In addition, increased $\mathrm{NO}_{x}$ emissions from agricultural activity enhance the shortlived $\mathrm{O}_{3}$ forcing from this sector. 


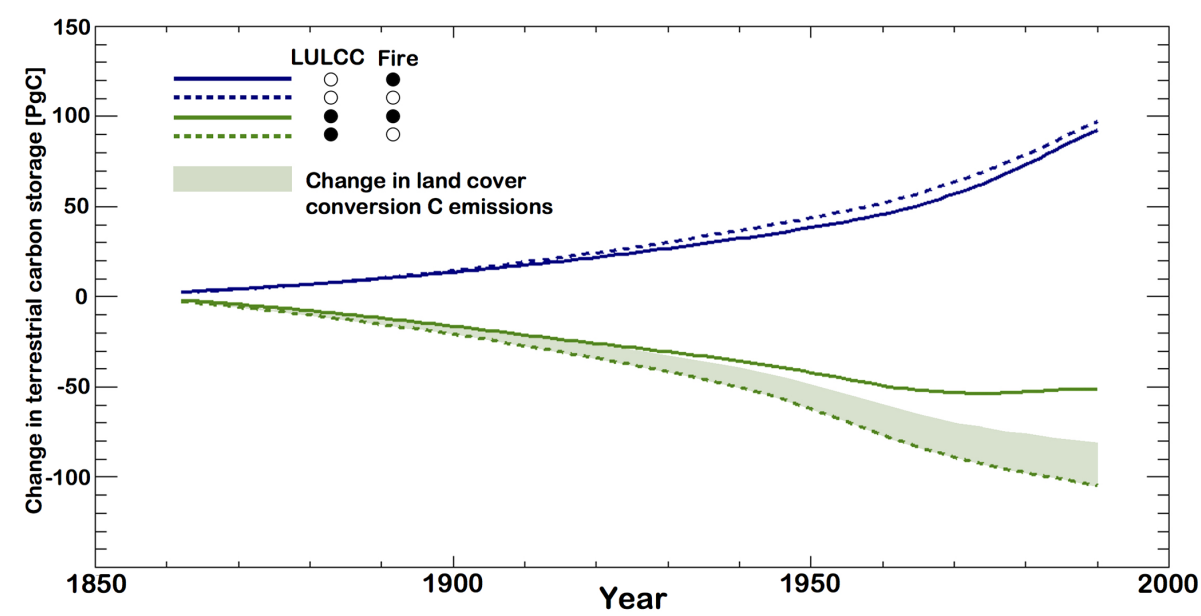

Figure 3. Time series of the historical change in global terrestrial carbon storage for Community Land Model (CLM) simulations with and without LULCC (green and blue, respectively), and with and without fires (solid and dashed, respectively), relative to the year 1850. Changes in carbon storage due to increased land cover conversion carbon emissions when fires are removed are shaded in light green. The time series is smoothed with a 25-year running average.

While agricultural emissions and land cover change projections for each RCP were developed jointly by an integrated assessment model (IAM), the land cover change projections were modified during harmonization for terrestrial model use (Di Vittorio et al., 2014). This means that the sector RFs calculated in this study may be in conflict with the original LULCC storylines of the IAMs, and, therefore, it may be more informative to consider the RF from each sector as a range of possible outcomes, separately from their respective RCPs.

\subsection{Fire-LULCC interactions}

Non-deforestation fires are often considered carbon-neutral, meaning the carbon sequestered during post-fire regrowth roughly balances the carbon emitted. But this is not the case for periods of trending global fire activity, as during rapid climate change (Prentice et al., 2011) or ecosystem shifts (Runyan et al., 2012), when the fire carbon source and sink are out of balance and atmospheric $\mathrm{CO}_{2}$ concentrations are affected on a long-term basis (Ward et al., 2012). Anthropogenic changes to land cover can also alter wildfire area burned and emissions (Harrison et al., 2010; Marlon et al., 2008). However, it is difficult to isolate the impact of LULCC on global fire activity from the other important drivers such as climate (Pechony and Shindell, 2010). Perhaps for this reason, interactions between LULCC and wildfire have not been explored in detail on a global scale. Previous studies have generally concluded that, globally, fires have been reduced by increases in land management over the 20th century (Houghton et al., 1999; Marlon et al., 2008; Kloster et al., 2012; Yang et al., 2014). However, local- and regionalscale research show vastly different fire responses to land cover change and land management in different ecosystems
(Cochrane and Barber, 2009; Archibald et al., 2009; Runyan et al., 2012). Satellite observations of African savannah show that a portion of the decrease in fires that occurred over the first decade of the 21 st century resulted from conversion of savannah to croplands (Andela and van der Werf, 2014). While in the Amazon region of South America, wildfires probably increase in occurrence and area burned following landscape fragmentation, especially from deforestation (Nepstad et al., 1999, 2006; Aragao and Shimabukuro, 2010; Chen et al., 2013).

Local effects such as those that occur in the Amazon are generally not well represented by global-scale fire models that do not capture ecosystem edge effects or small-scale variations in surface hydrology. Area burned by fires in the Kloster et al. (2010) model used here responds to changes in biomass availability, meaning a decrease in vegetation, such as that following deforestation, leads to a decrease in area burned. Therefore, global-scale conversion of forests to grassland or crops, a source of carbon to the atmosphere, leads to a decrease in fire emissions of carbon to the atmosphere. From 1850 to 2004, fires were responsible for a greater than $50 \mathrm{PgC}$ decrease in total carbon emissions from LULCC (Fig. 3, difference between dashed and solid green lines). About half of this decrease can be attributed to an artifact of our experimental setup that results from the removal of fires from the Community Land Model (CLM) simulations. Fires are a substantial loss term for terrestrial carbon and when they are excluded from the CLM simulations, terrestrial carbon storage increases everywhere fires normally occur (Ward et al., 2012). As a result, in the "no-fire" simulations, carbon emissions from land cover conversions are enhanced because there is more aboveground carbon available to be released. We calculate the difference in carbon emissions from land cover conversions in the simulations with 


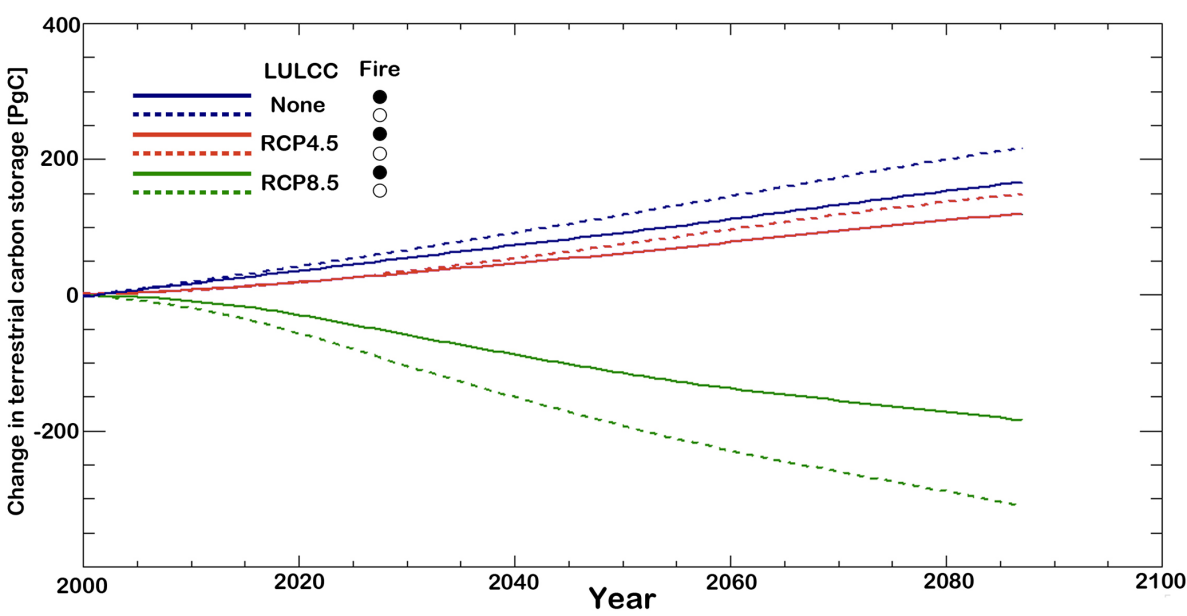

Figure 4. Time series of the projected change in global terrestrial carbon storage for CLM simulations with RCP4.5, with RCP8.5, and without LULCC (red, green, and blue, respectively), and with and without fires (solid and dashed, respectively), relative to the year 2000. The time series is smoothed with a 25 -year running average.

and without fire and plot this as the shaded area in Fig. 3. We do not include this reduction in terrestrial carbon emissions from fires when computing the $\mathrm{CO}_{2} \mathrm{RF}$ from the wildfire response to LULCC. We do consider the remaining reduction in carbon emissions shown in Fig. 3 (space between shading and solid green line), which results from an increase in the terrestrial carbon sink as fires are reduced globally by land cover changes. Strictly LULCC-caused changes in fire activity are included here and using our methodology, these are isolated from changes due to trends in global climate or atmospheric $\mathrm{CO}_{2}$. An even larger reduction in carbon emissions from the wildfire response is projected for RCP8.5 LULCC, whereas global carbon emissions are not affected greatly by the LULCC associated with RCP4.5 (Fig. 4).

\subsection{Land use RF by source location}

The sources of the LULCC sector RFs are spatially heterogeneous and depend strongly on the LULCC projection (Fig. 5). Major present-day agricultural regions that are projected to remain productive during this century, in particular India, eastern China, and the central United States (Hurtt et al., 2011), contribute $70-80 \%$ of the global LULCC RF in 2010 as well as in the RCP4.5 and RCP6.0 scenarios (Fig. 5). In contrast, the remaining scenarios all exhibit a substantial tropical source of positive RF from LULCC. Direct modifications to land cover dominate the RF from the tropics, although there are subtropical areas where agriculture contributes the most of all sectors, especially for RCP8.5 LULCC (Fig. 6). Similarly, in 2010, direct modification to land cover is the dominant tropical source of RF (Fig. 6). In all cases, there are regions of negative forcing from LULCC, particularly in northern China and Mongolia, although these are smaller in magnitude than the positive forcings.
Comparing the latitudinally averaged total RF from LULCC to the RF from other anthropogenic activities, mainly fossil fuel burning, demonstrates the role of LULCC as the major tropical source of positive anthropogenic forcing both in 2010 and in the future projections. We are only able to compare the LULCC RFs against non-LULCC RFs from RCP4.5 for which fossil fuel burning emissions were used to compute background constituent concentrations in Ward et al. (2014). Note that the contribution of non-LULCC activities to global RF would be larger if RCP6.0 or RCP8.5 were shown. In the TEC, the tropical RF from LULCC nearly surpasses the northern hemispheric extra-tropical RF from other anthropogenic activities (RCP4.5), largely due to direct modifications of the land cover (Figs. 5 and 6).

We plot the ratios of LULCC RF to total anthropogenic $\mathrm{RF}$ to illustrate that on an individual country level there is a substantial range in the proportion of total anthropogenic RF that can be ascribed to LULCC activities (Figs. 7 and 8). The forcing from developed countries, such as the United States, Canada, Japan, and the European Union countries, is dominated by fossil fuel burning in the year 2010 (Fig. 7a). This is also true for many African countries where the total anthropogenic RF is small (Ward and Mahowald, 2014). The important developing countries for global, anthropogenic climate change, China, India, Brazil, and Indonesia (Ward and Mahowald, 2014), all contribute more LULCC RF than fossil fuel burning RF. These differences in the source of RF between developed and developing countries were noted by Pongratz and Caldeira (2012) for LULCC CO 2 emissions. Here we show that the same is true when non- $\mathrm{CO}_{2}$ greenhouse gas and aerosol forcings are included in the analysis. Standard climate change metrics, such as $\mathrm{CO}_{2}$ equivalents, often do not incorporate short-lived climate forcers (Ward and Mahowald, 2014). If only greenhouse gas forcing agents are included in the comparison, China is more 

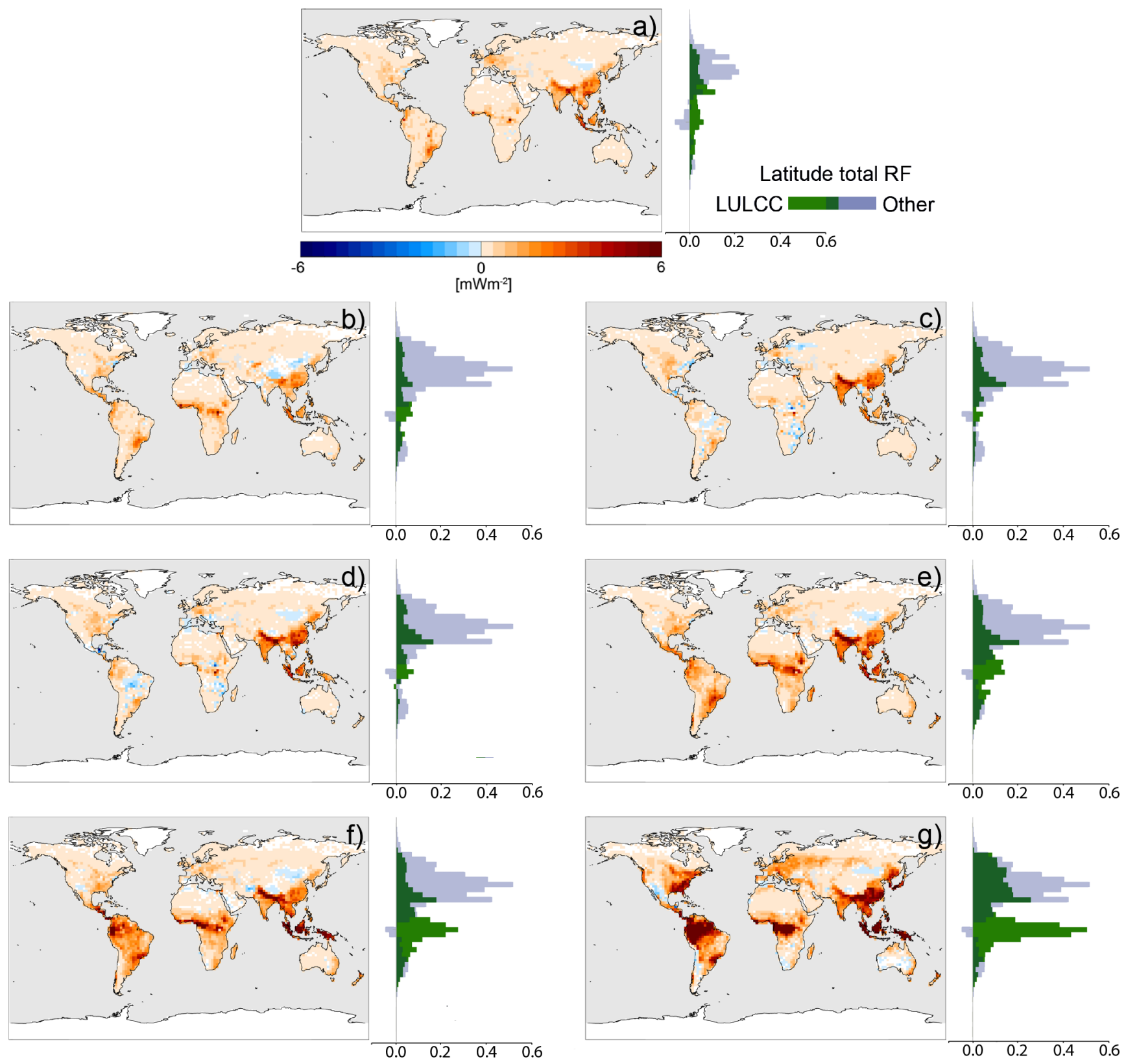

Figure 5. Spatial distribution of the sources of LULCC RF for (a) 2010, and the year 2100 given the projections of (b) RCP2.6, (c) RCP4.5, (d) RCP6.0, (e) RCP8.5, (f) trop-BAU, and (g) TEC. Latitude band total RFs are shown to the right of each spatial plot with the LULCC totals in green compared to the totals from other anthropogenic activities from (a) the year 2010, and (b-g) the year 2100 RCP4.5, in light purple.

evenly split between LULCC and fossil fuel sources of RF (Fig. 7b). Tropical countries are more consistently dominated by LULCC without the contributions of aerosols, which are often negative. Similar differences between country groups are projected to persist in the RCP4.5 scenario, although fossil fuel RF plays a larger role in general (Fig. 8).

\subsection{Future RF of land use activities}

In this section, we address whether a simple linear regression approach could be used to estimate the RF of future changes in forest and crop area. We have calculated the RF from different LULCC sectors for six possible future scenarios, providing six data points per grid cell in the tropics to test this approach (in the extra-tropics there are only 5 data points since the Trop-BAU and RCP8.5 emissions are the 

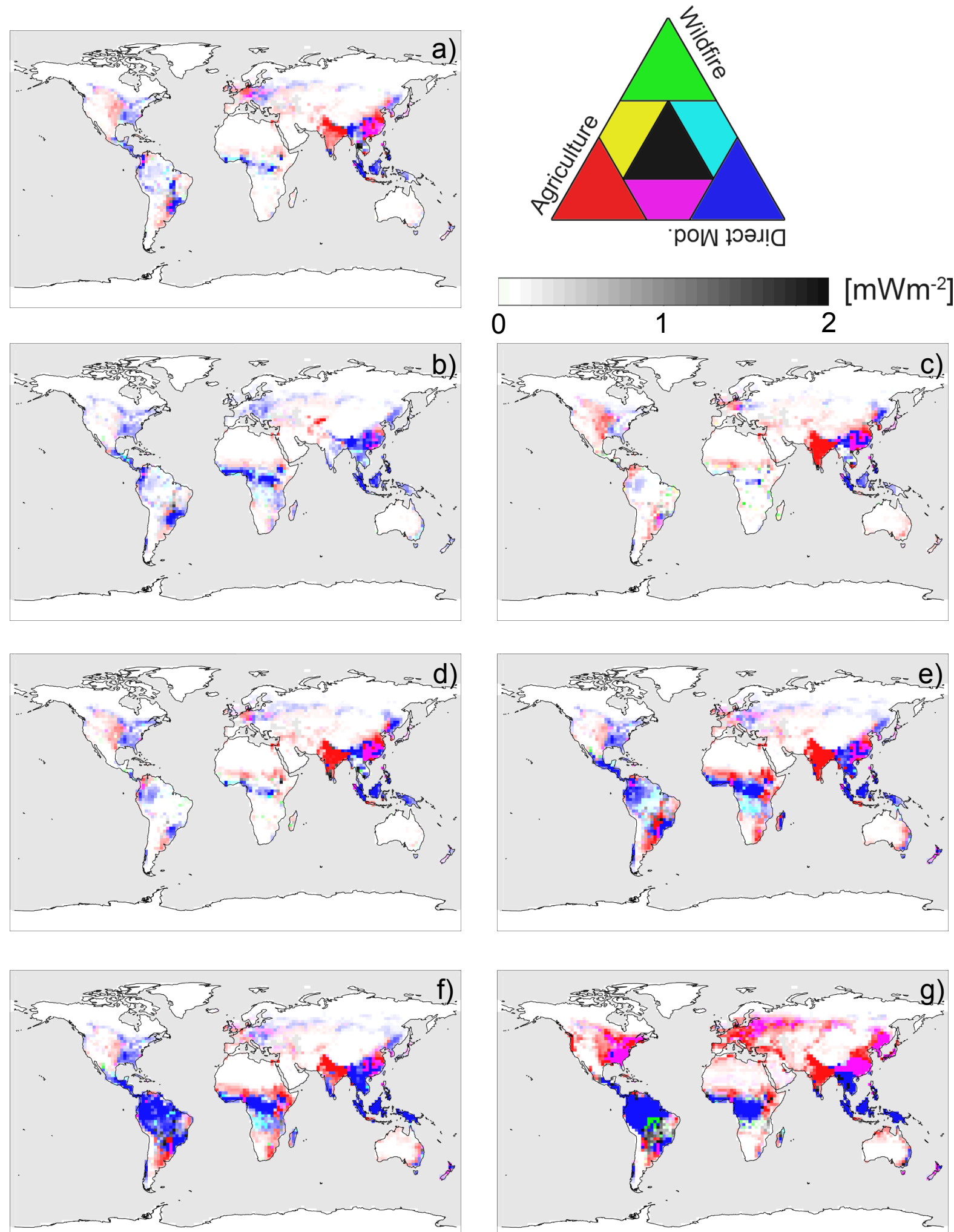

Figure 6. Spatial distribution of the sources of LULCC RF by sector for (a) 2010, and the year 2100 given the projections of (b) RCP2.6, (c) RCP4.5, (d) RCP6.0, (e) RCP8.5, (f) trop-BAU, and (g) TEC. The colors indicate the proportion of RF (assessed as absolute magnitudes) from direct modifications (blue), agriculture (red), and changes to wildfires (green). Where more than one sector contributes to the total RF, the colors are blended according to the color triangle in the top right of the figure. The darkness of the coloring indicates the total magnitude of the RF at each point following the scale in the top right of the figure. 

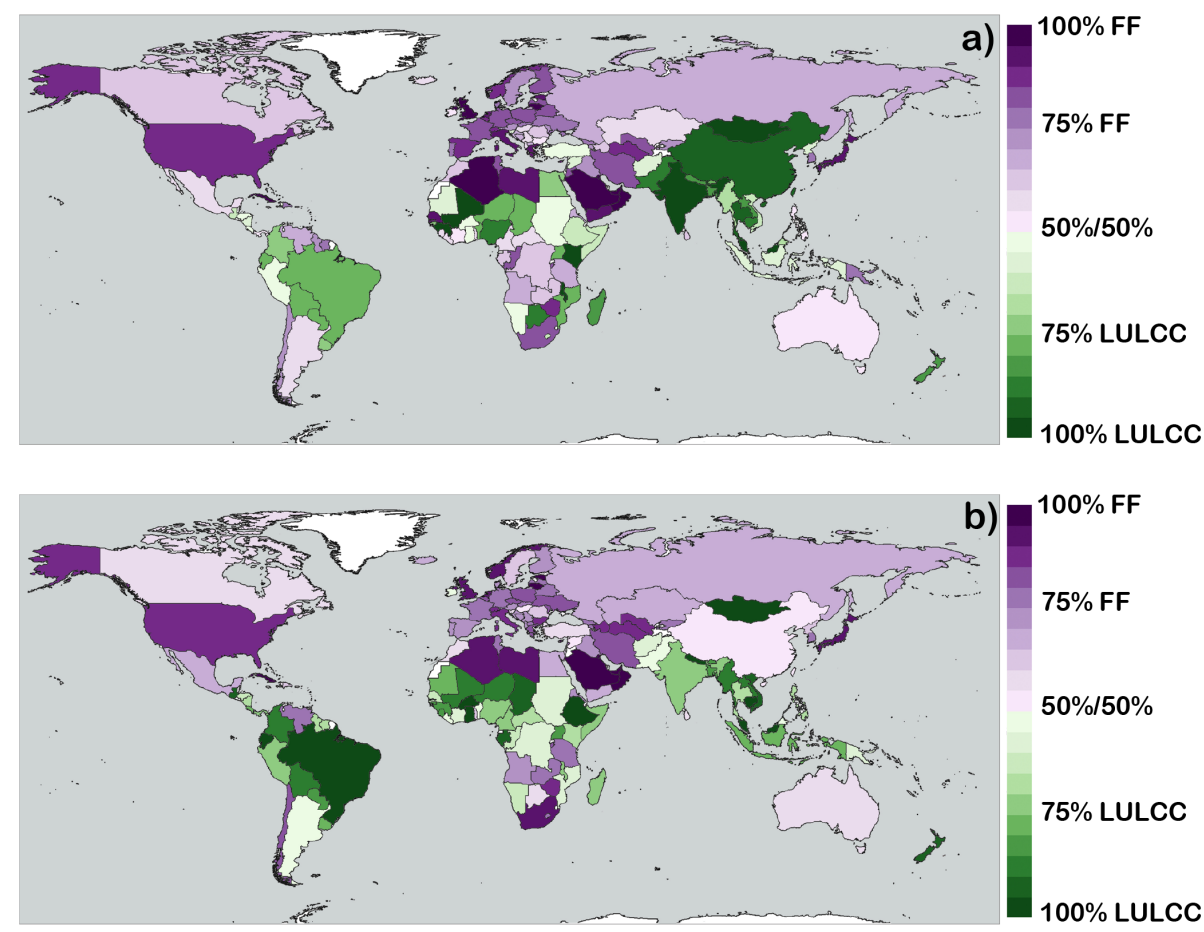

Figure 7. The ratio of the absolute value of LULCC RF to the absolute value of the RF of fossil fuel burning activities computed for each country for the year 2010 including (a) all forcing agents, and (b) only greenhouse gas forcing agents.
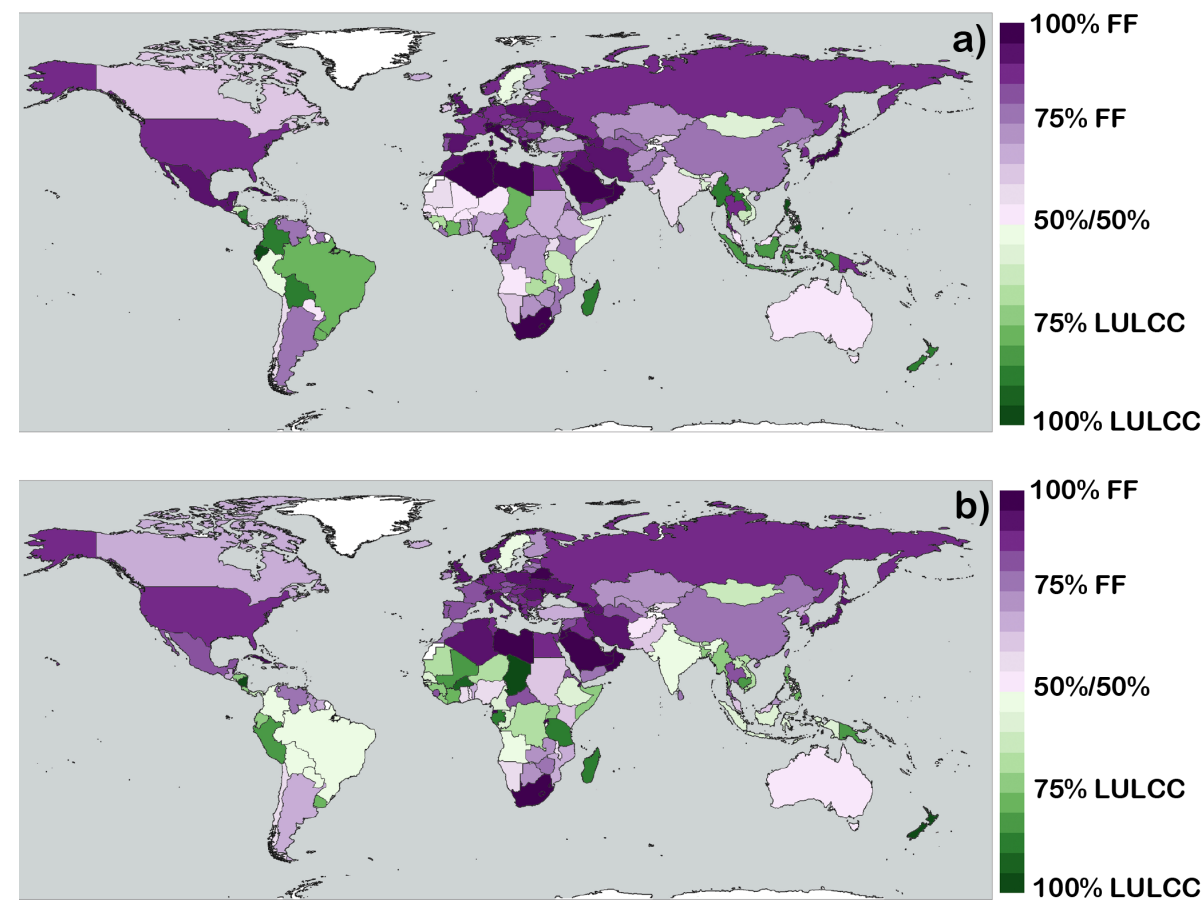

Figure 8. The ratio of the absolute value of LULCC RF to the absolute value of the RF of fossil fuel burning activities computed for each country for the year 2100 and the RCP4.5 scenario anthropogenic emissions and land cover change, including (a) all forcing agents, and (b) only greenhouse gas forcing agents. 

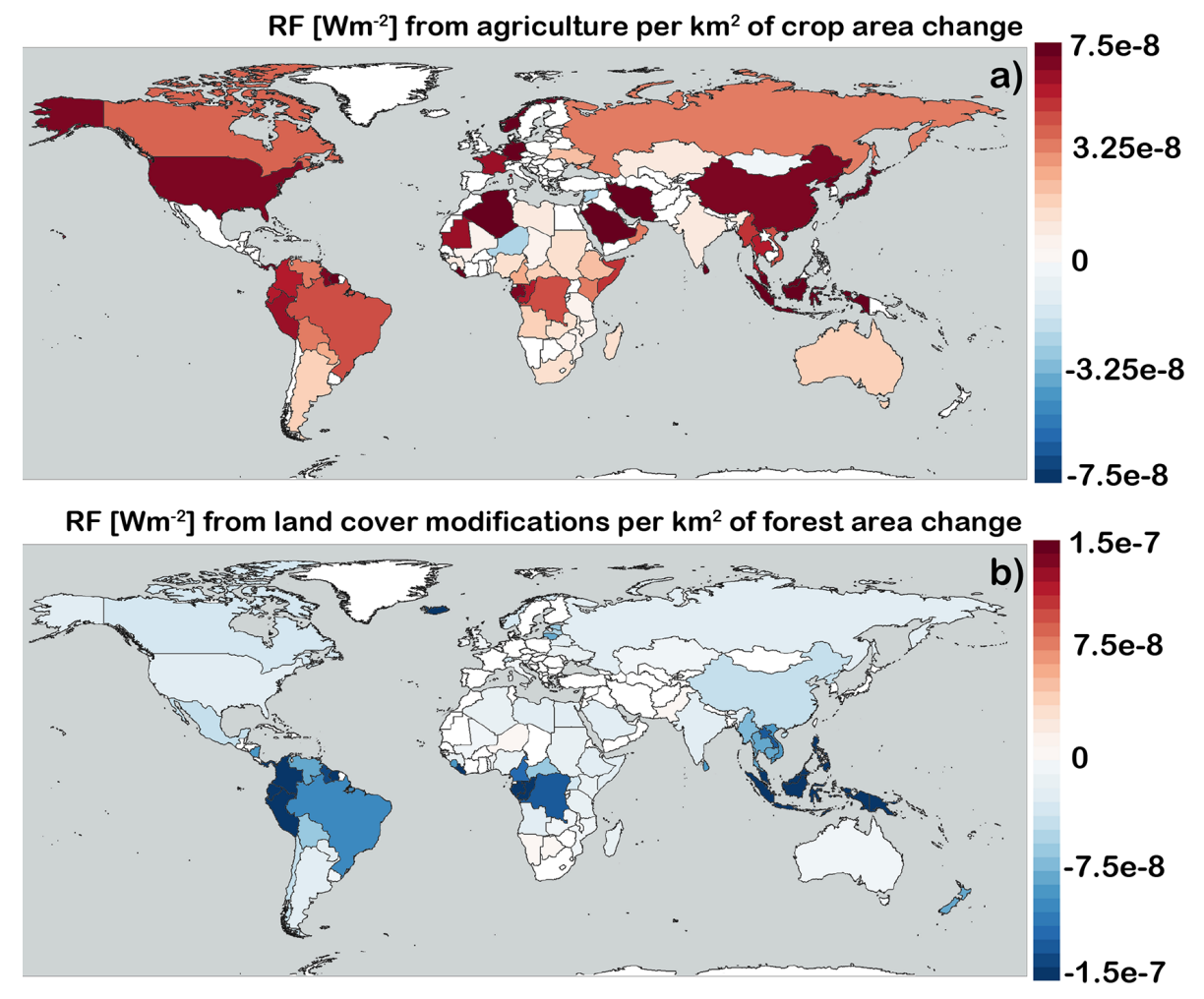

$7.5 e-8$

0

$-7.5 e-8$

$-1.5 e-7$

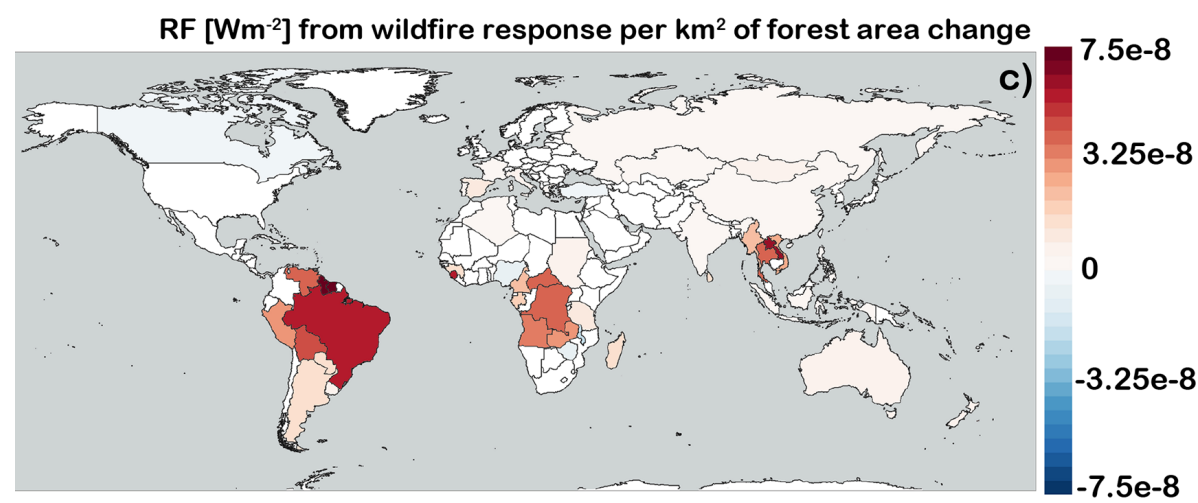

Figure 9. Slope of the regression of year $2100 \mathrm{RF}$ from (a) agricultural activities, (b) direct modifications to land, and (c) associated changes in wildfires between 2010 and 2100 onto the change in (a) global crop area and (b), (c) global forest area between 2010 and 2100 for each country. Regression coefficients are plotted when the relationship between RF and changes in land cover is significant at a $95 \%$ confidence level (two-tailed test) using the Spearman rank correlation coefficient.

same). Here we regress the RF from the year 2100, referenced against the year 2010, onto forest area change over the same period for the direct modification and wildfire sectors (increases in forest area are shown with a positive sign), and onto crop area change for the agriculture sector (increases in crop area are shown with a positive sign) for each country, using a $1.9^{\circ}$ latitude by $2.5^{\circ}$ longitude grid.

The regression coefficients for the agriculture sector are generally positive, indicating that an increase in crop area leads to a positive RF from that sector. The magnitudes of the regression coefficients are high in tropical countries but also in northern hemisphere extratropical countries with major agricultural sectors. The relationship is significant at a $95 \%$ confidence level (two-tailed test), using the Spearman rank correlation coefficient, for most countries (Fig. 9a). Most countries also have a statistically significant regression between direct modification RF and the change in forest area, using the same significance test (Fig. 9b). Here deforestation always leads to positive RF, including in the high latitudes where negative forcings from land albedo change play a larger role. The relationship is particularly strong in tropical countries and appears to be linked to the terrestrial carbon storage such that the impact of deforestation on RF is greatest for the high carbon-storage regions of the Amazon and cen- 
tral African rain forests. The regression of the wildfire sector $\mathrm{RF}$ onto forest area change does not produce as many statistically significant regression coefficients, but does result in a positive relationship in the deep tropics of South America and Africa and a weak relationship in several subtropical and extra-tropical countries (Fig. 9c). As forest area is reduced, the wildfire emissions simulated by CLM in deforested areas are also reduced. Notably in Brazil and Bolivia, the positive relationship between RF and forest area change through the wildfire feedback is almost as strong as the negative relationship through direct modification of the land cover (Fig. 9b and c; note the different scales of these two figure panels). This result warrants further study given the possible shortcomings of the fire model used in this study for simulating LULCC-fire interactions in the Amazon (Sect. 3.2).

\section{Discussion}

Discussions of the climate impacts of LULCC activities are often limited to the effects of deforestation (e.g. Brovkin et al., 2013; Boysen et al., 2014; Bala et al., 2007). Here we find a substantial contribution to anthropogenic climate forcing from agricultural activities in 2010 and in most of the future projections. Fertilizer application drives both a positive forcing, as $\mathrm{N}_{2} \mathrm{O}$ emissions, and a negative forcing, through fertilizing natural vegetation after transport and deposition of $\mathrm{N}$ and drawing down $\mathrm{CO}_{2}$ from the atmosphere. We find that these forcings partially cancel each other out and the differences in the agricultural RF between future scenarios are mainly driven by emissions of $\mathrm{CH}_{4}$ from livestock and rice cultivation.

There is now recognition of the importance of atmospheric chemistry in determining the sum forcing of LULCC (e.g. Heald et al., 2008; Ganzeveld et al., 2010). Unger (2014) found a global RF of $-0.11 \pm 0.17 \mathrm{~W} \mathrm{~m}^{-2}$ from the modified biogenic volatile organic compound emissions that resulted from historical LULCC. Here we attribute most of the important atmospheric chemistry changes, including $\mathrm{O}_{3}$ production and loss, and $\mathrm{CH}_{4}$ lifetime, to modified wildfire activity, although we also simulate biogenic volatile organic compound (BVOC) emissions and their impacts on chemistry. While previous studies have assessed the response of fire $\mathrm{C}$ emissions to LULCC on a global scale (Houghton et al., 1999; Marlon et al., 2008; Kloster et al., 2012), we quantify this response as a RF, including a range of forcing agents in addition to $\mathrm{CO}_{2}$. Both in 2010 and in the future scenarios, the wildfire response to LULCC leads to a negative forcing, in most cases a result of reduced $\mathrm{CO}_{2}$ emissions from fires. However, this response is complex and, as in the wildfire response to RCP4.5 land use and land cover change, it can depend on the chemistry of fire emissions that affects non- $\mathrm{CO}_{2}$ greenhouse gases as much as it depends on changes in terrestrial $\mathrm{CO}_{2}$ sources and sinks. The $\mathrm{RF}$ of the wildfire response is not generally predictable using a simple linear regression with forest area change. However, fire-LULCC interactions may be associated with a considerable global forcing that acts to reduce the total LULCC RF (Fig. 2). This demonstrates the importance of accounting for these interactions in global carbon cycle models and working toward better model representation of fire responses to land cover change.

When interpreting these results it is important to note that while the set of forcing agents considered in this study is nearly comprehensive, feedbacks of LULCC onto the hydrological cycle and clouds were not included in this study. These feedbacks could lead to a net cooling of global surface temperatures from deforestation even when accounting for increased $\mathrm{CO}_{2}$ from forest removal (Bala et al., 2007). However, Davin and Noblet-Ducoudre (2010) show that the nonradiative biogeophysical forcings of land cover change, associated with evapotranspiration and surface roughness, could be a net warming. A study using CLM in a fully coupled climate model suggests that the total forcing of biophysical effects, including cloud cover feedbacks, associated with historical land cover change are probably small compared to the forcing from greenhouse gases emitted by the same activities (Lawrence and Chase, 2010). These forcings and feedbacks are not easily quantified with the RF metric (Pielke et al., 2002). A different approach to our stated aim of identifying the sources of climate impacts from LULCC could use global surface temperature change as a metric instead of radiative forcing. With this approach, the various biogeochemical and biogeophysical effects could be combined.

However, by attributing forcing from LULCC activities to specific sectors and locations, given the set of forcing agents included in this study, we gain a better understanding of where efforts to mitigate anthropogenic climate changes could be focused. Future forcing from direct modifications to land cover is scalable to changes in forest area (Fig. 9). The potential importance and scalability of RF from the direct modifications sector lends support to the REDD strategy of valuing land based on the potential $\mathrm{C}$ emissions from deforestation (Lubowski and Rose, 2013). This strategy could be particularly effective in the tropics, although LULCC-related changes in wildfire activity modify the overall LULCC contribution to global RF. 


\section{Appendix A: Summary of RF computations}

In the remainder of this section we provide a summary of the different methodologies used to compute the RFs from LULCC for all forcing agents in Ward et al. (2014). The order of forcing agents in this summary is $\mathrm{CO}_{2}, \mathrm{~N}_{2} \mathrm{O}, \mathrm{CH}_{4}$, $\mathrm{O}_{3}$, aerosol effects, land albedo change, and biogeochemical feedbacks onto $\mathrm{CO}_{2}$ concentrations. The anthropogenic RF of an atmospheric constituent is computed from the change in the concentration of that constituent due to anthropogenic activities over a reference time period, often a preindustrial date to the present. Therefore, computing RFs is, for most forcing agents, a three-step process beginning with the assembling of the emissions data set of interest, using the emissions to calculate a change in concentration of the forcing agent, and finally assessing the RF from the concentration change. Forcing agents with different atmospheric lifetimes, for example $\mathrm{N}_{2} \mathrm{O}$ (> 100 years) compared to aerosols (days to weeks), require different methods for determining concentration changes.

Global $\mathrm{CO}_{2}$ emissions from LULCC are considered to be uncertain. Model inter-comparison studies produce a large range in values for this quantity (Brovkin et al., 2013) and even differences in terminology play a role in the uncertainty (Pongratz et al., 2014). Using a modified Community Land Model version 3.5 (Oleson et al., 2008; Thornton et al., 2009), Ward et al. (2014) compute the net LULCC carbon flux from the year 1850 through 2100 as the difference in terrestrial carbon storage between simulations with land cover change and land use, and a reference simulation with preindustrial land cover (year 1850). The LULCC flux was adjusted downward to account for the $\mathrm{CO}_{2}$ fertilization feedback (Strassmann et al., 2008), which leads to double-counting of $\mathrm{CO}_{2}$ emissions in uncoupled terrestrial model simulations (Pongratz et al., 2014; Arora and Boer, 2010). The double-counting occurs in transient $\mathrm{CO}_{2}$ simulations when no LULCC is included but atmospheric $\mathrm{CO}_{2}$ concentrations reflect the impact of LULCC, thereby artificially increasing $\mathrm{CO}_{2}$ fertilization of vegetation. The airborne fraction of $\mathrm{CO}_{2}$ emissions, that is the portion of emitted $\mathrm{CO}_{2}$ remaining in the atmosphere at some future time, was derived from a pulse response function characteristic of rising $\mathrm{CO}_{2}$ concentrations (following the methodology of Randerson et al., 2006 and O'Halloran et al., 2012). In this way, the history of $\mathrm{CO}_{2}$ emissions from different sectors of LULCC is accounted for in these calculations. From the change in $\mathrm{CO}_{2}$ concentration, the RF of $\mathrm{CO}_{2}$ emitted by LULCC activities was calculated with the simple expression from Ramaswamy et al. (2001).

Nitrous oxide is emitted by livestock and by the application of fertilizer onto crops. LULCC also has a minor impact on $\mathrm{N}_{2} \mathrm{O}$ concentrations by modifying wildfire emissions. $\mathrm{N}_{2} \mathrm{O}$ has a long lifetime in the troposphere (greater than 100 years; Meinshausen et al., 2011) and its chemistry can be treated with a simple box model approach. Ward et al. (2014) used the Kroeze et al. (1999) box model to calculate the change in $\mathrm{N}_{2} \mathrm{O}$ concentrations resulting from the emissions associated with LULCC. RFs were calculated with the simple expression recommended by Ramaswamy et al. (2001).

Methane concentrations are modified directly by emission of $\mathrm{CH}_{4}$ from LULCC activities, and indirectly by changes to the oxidation capacity of the troposphere that impacts $\mathrm{CH}_{4}$ lifetime. Emissions of $\mathrm{CH}_{4}$ from LULCC have been compiled for the historical time period (Lamarque et al., 2010) and for the RCP scenarios (Vuuren et al., 2007; Wise et al., 2009; Fujino et al., 2006; Riahi et al., 2007). In addition, small changes in $\mathrm{CH}_{4}$ emissions from wildfires are caused by LULCC and were simulated by CLM for these calculations (Ward et al., 2014). A box model approach from Ward et al. (2012) was used to determine the direct modifications to $\mathrm{CH}_{4}$ concentrations from LULCC. To determine changes to the $\mathrm{CH}_{4}$ lifetime, Ward et al. (2014) simulated atmospheric chemistry within the Community Atmosphere Model version 4 (Hurrell et al., 2013; Gent et al., 2011; Emmons et al., 2010 ) with LULCC emissions of non-methane hydrocarbons (NMHCs) and $\mathrm{NO}_{x}$, and without these emissions. The different emissions lead to changes in global hydroxyl radical, $\mathrm{OH}$, concentrations. The $\mathrm{CH}_{4}$ lifetime can be computed from the new OH concentration (Naik et al., 2005; Ward et al., 2012) and the changes to $\mathrm{CH}_{4}$ concentration from LULCC activities were adjusted according to the new lifetime (Ward et al., 2014). The RF is calculated using the simple expression recommended by Ramaswamy et al. (2001) for $\mathrm{CH}_{4}$.

LULCC impacts tropospheric $\mathrm{O}_{3}$ concentrations by emitting $\mathrm{NO}_{x}$ (such as from fertilizer application) and by modifying emissions of NMHCs from vegetation and from fires. The response of $\mathrm{O}_{3}$ concentrations to the changes in these emissions cannot be represented with a simple model approach but involves a complex set of chemical reactions. Ward et al. (2014) calculated the LULCC contribution to tropospheric $\mathrm{O}_{3}$ with the same set of CAM4 simulations used to assess the $\mathrm{CH}_{4}$ lifetime. The radiative impact of the changes in $\mathrm{O}_{3}$ was determined with the Parallel Offline Radiative Transfer (PORT) tool (Conley et al., 2013) for both shortwave and longwave interactions. The response of $\mathrm{O}_{3}$ on long timescales to changes in $\mathrm{CH}_{4}$ concentrations, known as the primary mode response, was included in the $\mathrm{LULCC} \mathrm{O}_{3} \mathrm{RF}$ calculation following Prather et al. (2001).

Emissions of several aerosol species are impacted by land use and land cover change. Ward et al. (2014) considered changes in biogenic secondary organic aerosol from modified leaf area index, changes in dust emissions from cultivation, and changes in fire emissions of black carbon (BC), organic carbon (OC), and sulfate aerosols from LULCC. Changes in aerosol concentrations were computed with a set of CAM version 5 simulations with the Modal Aerosol Model (MAM3) (Liu et al., 2012), with and without the LULCC emissions. Radiative effects of the aerosols, both direct effects and indirect effects on clouds, were diagnosed 
online, giving values for ERFs for the LULCC aerosol emissions.

Changes to the land surface albedo from land cover change were derived directly from the CLM simulations in Ward et al. (2014). The simulated changes in albedo alter the fraction of incident solar radiation that is reflected back into the atmosphere. The reflected solar radiation is multiplied by the fraction of outgoing radiation that reaches the top of the atmosphere at each grid point of a model climatology characteristic of the year 2000 in which clouds and aerosol scattering are implicit. The radiative forcing is then simply the difference in top-of-atmosphere net solar radiative flux caused by the changes in albedo. Additional forcing from modified albedo following fires was also included for the change in fires due to LULCC, following the offline analysis of Ward et al. (2012). Feedbacks of nitrogen deposition by aerosols and feedbacks of climate change onto the carbon cycle have been identified and quantified by Mahowald (2011). The magnitudes of these feedbacks for LULCC were estimated by Ward et al. (2014) and included in the total $\mathrm{CO}_{2} \mathrm{RF}$.

\section{Appendix B: Assigning forcings to sectors}

In this Appendix we discuss the methods for attributing forcing from individual trace gas and aerosol agents to the three LULCC sectors defined in Sect. 2.3. As mentioned in Sect. 2.3, apportioning of the $\mathrm{O}_{3}$ forcing is based on $\mathrm{NO}_{x}$ emissions. $\mathrm{NO}_{x}$ emissions are also used to apportion the forcing of indirect changes to $\mathrm{CH}_{4}$, while the forcing from direct changes to $\mathrm{CH}_{4}$ can be assigned to categories based on $\mathrm{CH}_{4}$ emissions. To properly divide the direct aerosol effect between categories we need to treat different aerosol species separately. The magnitude and even the sign of the effective RF of aerosols depend on the properties of the different aerosol species. Sulfate and OC aerosols scatter shortwave radiation while $\mathrm{BC}$ absorbs shortwave radiation and can be a source of heat in the troposphere. Ward et al. (2014) diagnose the direct effect of all LULCC aerosols, and for five different aerosol species: $\mathrm{BC}, \mathrm{OC}$, sulfate, mineral dust, and secondary organic aerosol (SOA), from the CAM5 simulations. In these online diagnostics, the radiative transfer scheme is passed through several times, each time with a different aerosol species removed. The resulting direct effect forcing for individual aerosol species is approximate since water uptake onto aerosols is unaffected by the removal of aerosols in the radiative transfer passes.

With these forcings for individual aerosol species estimated, the direct ERF attributed to LULCC is apportioned into sectors by the relative emissions of each of the five species listed above. The indirect ERF attributed to LULCC is apportioned according to the fraction of aerosol number concentration emissions originating from each sector.

$\mathrm{N}_{2} \mathrm{O}$ emissions, similar to emissions of $\mathrm{NO}_{x}$, are dominated by activities associated with the agriculture sector, but deforestation fires and wildfires also change $\mathrm{N}_{2} \mathrm{O}$ concentrations. The forcing from LULCC $\mathrm{N}_{2} \mathrm{O}$ cannot be divided into sectors based on contemporaneous emissions of $\mathrm{N}_{2} \mathrm{O}$ because its long lifetime in the atmosphere requires that emission history be taken into account. Therefore, we apply the box model technique of Kroeze et al. (1999) and used by Ward et al. $(2012,2014)$ to emissions of $\mathrm{N}_{2} \mathrm{O}$ from each individual sector to determine the contribution of each sector to the total LULCC $\mathrm{N}_{2} \mathrm{O}$ RF for each year from 1850 to 2100 , and for each future scenario. The box model simulates changes in $\mathrm{N}_{2} \mathrm{O}$ concentration with time, $\mathrm{d} C / \mathrm{d} t$, as a result of yearly emissions, $E$. We also include a variable $\mathrm{N}_{2} \mathrm{O}$ lifetime, $\tau$, that is a function of its own concentration, following Meinshausen et al. (2011):

$$
\begin{aligned}
& \frac{\mathrm{d} C}{\mathrm{~d} t}=\frac{E}{S}-\frac{C}{\tau} \\
& \tau=\tau_{\mathrm{C}}\left(\frac{C}{C_{\mathrm{C}}}\right)^{-0.05} .
\end{aligned}
$$

In Eq. (1), $S$ is a conversion factor, $4.8 \mathrm{Tg} \mathrm{N} \mathrm{ppbv}^{-1}$, and $t$ is time in years.

Apportioning the $\mathrm{CO}_{2} \mathrm{RF}$ into sectors presents a similar challenge because of its long residence time in the atmosphere. We assume that agricultural activities are carbon neutral, sequestering the same amount of carbon in plant regrowth that is lost through waste burning, tillage, and harvesting. Then, we separate the carbon emissions from land cover changes and wood harvesting from LULCC-modified wildfire emissions using a set of CLM simulations in which fires are turned off. The terrestrial carbon storage in these simulations is compared with the reference state carbon storage from the Ward et al. (2014) CLM simulations with and without LULCC, but all including wildfires. For these simulations we follow the same protocol as in Ward et al. (2014) and several previous studies (e.g. Kloster et al., 2010, 2012; Ward et al., 2012). The land model is forced from 1850 to 2004 with reanalysis atmospheric forcing from Qian et al. (2006). The reanalysis temperature, precipitation, wind, solar forcing, and humidity from 1948 to 1972 are used to force the model during preindustrial spinup and from 1850 to 1948, followed by the 1948 to 2004 reanalysis to force CLM in the corresponding years. CLM is coupled to a processbased fire model (Kloster et al., 2010). Fire area burned is predicted based on the probability of ignition by lightning or human activities, the fuel moisture, and the available biomass in a grid cell. In this scheme, different PFTs exhibit different mortality rates and combustion completeness. The combustion completeness of crop PFTs is set to zero. Existing PFTs do not change type due to fires or climate in this version of CLM.

Deforestation fires occur separately from wildfires in the Kloster et al. (2010) model. In this scheme, after deforestation, vegetation carbon that is normally lost to the atmosphere through decomposition may be converted to atmo- 
spheric $\mathrm{CO}_{2}$ and other trace gas species immediately through fire if a low soil moisture condition is met. In the Kloster et al. (2010) fire model used here, deforestation fires do not impact the amount of carbon removed from the terrestrial biosphere by land cover change, but do impact the timing of the carbon loss. The more relevant impact of deforestation fires in this scheme is in the additional emissions of trace gases and aerosol species when carbon is burned, rather than lost through decomposition.
We perform two historical simulations from 1850 to 2004 with CLM, one with LULCC and one without LULCC, and both without wildfires, branched from a preindustrial spinup without fires (year 1850 land cover). This is followed by 14 future simulations without wildfires, including two simulations for each future scenario (six LULCC scenarios and the non-LULCC case), one for each of two sets of future atmospheric forcing. The future atmospheric forcing data sets, produced by Kloster et al. (2012), are derived from the output of two coupled climate models each following the Special Report on Emissions Scenarios A1B1 future scenario. The same atmospheric forcing is used for all future simulations regardless of the LULCC scenario and in this way the impacts of the LULCC can be isolated (Ward et al., 2014). 
Acknowledgements. We acknowledge support from the National Science Foundation (NSF) EaSM-1049033 and ETBC-1021613 and thank the two anonymous reviewers for their comments and suggestions. Model integrations were performed with support from the Computational \& Information Systems Lab at the National Center for Atmospheric Research, which is sponsored by the NSF.

Edited by: A. Kleidon

\section{References}

Andela, N. and van der Werf, G. R.: Recent trends in African fires driven by cropland expansion and El Nino to La Nina transition, Nat. Clim. Change, 4, 791-795, doi:10.1038/nclimate2313, 2014.

Aragao, L. E. and Shimabukuro, Y. E.: The incidence of fire in Amazonian forests with implications for REDD, Science, 328, 12751278,doi:10.1126/science.1186925, 2010.

Archibald, S., Roy, D. P., van Wilgen, B. W., and Scholes, R. J.: What limits fire? An examination of drivers of burnt area in Southern Africa, Global Change Biol., 15, 613-630, doi:10.1111/j.1365-2486.2008.01754.x, 2009.

Arora, V. K. and Boer, G. J.: Uncertainties in the 20th century carbon budget associated with land use change, Global Change Biol., 16, 3327-3348, doi:10.1111/j.1365-2486.2010.02202.x, 2010.

Bala, G., Caldeira, K., Wickett, M., Phillips, T. J., Lobell, D. B., Delire, C., and Mirin, A.: Combined climate and carbon-cycle effects of large-scale deforestation, P. Natl. Acad. Sci. USA, 104, 6550-6555, doi:10.1073/pnas.0608998104, 2007.

Betts, R.: Comparing apples with oranges, Nat. Rep. Clim. Change, 2, 7-8, doi:10.1038/climate.2007.74, 2008.

Boucher, O., Myhre, G., and Myhre, A.: Direct human influence of irrigation on atmospheric water vapour and climate, Clim. Dynam., 22, 597-603, doi:10.1007/s00382-004-0402-4, 2004.

Bowman, K., and Henze, D. K.: Attribution of direct ozone radiative forcing to spatially resolved emissions, Geophys. Res. Lett., 39, L22704, doi:10.1029/2012g1053274, 2012.

Boysen, L. R., Brovkin, V., Arora, V. K., Cadule, P., de NobletDucoudré, N., Kato, E., Pongratz, J., and Gayler, V.: Global and regional effects of land-use change on climate in 21 st century simulations with interactive carbon cycle, Earth Syst. Dynam., 5, 309-319, doi:10.5194/esd-5-309-2014, 2014.

Brovkin, V., Sitch, S., von Bloh, W., Claussen, M., Bauer, E., and Cramer, W.: Role of land cover changes for atmospheric CO2increase and climate change during the last 150 years, Global Change Biol., 10, 1253-1266, doi:10.1111/j.13652486.2004.00812.x, 2004.

Brovkin, V., Boysen, L., Arora, V. K., Boisier, J. P., Cadule, P., Chini, L., Claussen, M., Friedlingstein, P., Gayler, V., van den Hurk, B. J. J. M., Hurtt, G. C., Jones, C. D., Kato, E., de NobletDucoudré, N., Pacifico, F., Pongratz, J., and Weiss, M.: Effect of Anthropogenic Land-Use and Land-Cover Changes on Climate and Land Carbon Storage in CMIP5 Projections for the TwentyFirst Century, J. Climate, 26, 6859-6881, doi:10.1175/jcli-d-1200623.1, 2013.

Bryan, E., Ringler, C., Okoba, B., Koo, J., Herrero, M., and Silvestri, S.: Can agriculture support climate change adaptation, greenhouse gas mitigation and rural livelihoods? insights from Kenya, Climatic Change, 118, 151-165, doi:10.1007/s10584012-0640-0, 2012.

Chen, Y., Morton, D. C., Jin, Y., Collatz, G. J., Kasibhatla, P. S., van der Werf, G. R., DeFries, R. S., and Randerson, J. T.: Long-term trends and interannual variability of forest, savanna and agricultural fires in South America, Carbon Manage., 4, 617-638, doi:10.4155/cmt.13.61, 2013.

Cherubini, F., Bright, R. M., and Strømman, A. H.: Site-specific global warming potentials of biogenic $\mathrm{CO}_{2}$ for bioenergy: contributions from carbon fluxes and albedo dynamics, Environ. Res. Lett., 7, 045902, doi:10.1088/1748-9326/7/4/045902, 2012.

Chuang, C. C., Penner, J. E., Prospero, J. M., Grant, K. E., Rau, G. H., and Kawamoto, K.: Cloud susceptibility and the first aerosol indirect forcing: Sensitivity to black carbon and aerosol concentrations, J. Geophys. Res.-Atmos., 107, 4564, doi:10.1029/2000JD000215, 2002.

Claussen, M., Brovkin, V., and Ganopolski, A.: Biogeophysical versus biogeochemical feedbacks of large-scale land cover change, Geophys. Res. Lett., 28, 1011-1014, doi:10.1029/2000g1012471, 2001.

Cochrane, M. A. and Barber, C. P.: Climate change, human land use and future fires in the Amazon, Global Change Biol., 15, 601-612, doi:10.1111/j.1365-2486.2008.01786.x, 2009.

Conley, A. J., Lamarque, J.-F., Vitt, F., Collins, W. D., and Kiehl, J.: PORT, a CESM tool for the diagnosis of radiative forcing, Geosci. Model Dev., 6, 469-476, doi:10.5194/gmd-6-469-2013, 2013.

Davin, E. L. and de Noblet-Ducoudré, N.: Climatic impact of global-scale deforestation: Radiative versus nonradiative processes, J. Climate, 23, 97-112, 2010.

Davin, E. L., de Noblet-Ducoudré, N., and Friedlingstein, P.: Impact of land cover change on surface climate: Relevance of the radiative forcing concept, Geophys. Res. Lett., 34, L13702, doi:10.1029/2007g1029678, 2007.

Di Vittorio, A. V., Chini, L. P., Bond-Lamberty, B., Mao, J., Shi, X., Truesdale, J., Craig, A., Calvin, K., Jones, A., Collins, W. D., Edmonds, J., Hurtt, G. C., Thornton, P., and Thomson, A.: From land use to land cover: restoring the afforestation signal in a coupled integrated assessment-earth system model and the implications for CMIP5 RCP simulations, Biogeosciences, 11, 6435-6450, doi:10.5194/bg-11-6435-2014, 2014.

Elzen, M. G. J., Olivier, J. G. J., Höhne, N., and Janssens-Maenhout, G.: Countries' contributions to climate change: effect of accounting for all greenhouse gases, recent trends, basic needs and technological progress, Climatic Change, 121, 397-412, doi:10.1007/s10584-013-0865-6, 2013.

Emmons, L. K., Walters, S., Hess, P. G., Lamarque, J.-F., Pfister, G. G., Fillmore, D., Granier, C., Guenther, A., Kinnison, D., Laepple, T., Orlando, J., Tie, X., Tyndall, G., Wiedinmyer, C., Baughcum, S. L., and Kloster, S.: Description and evaluation of the Model for Ozone and Related chemical Tracers, version 4 (MOZART-4), Geosci. Model Dev., 3, 43-67, doi:10.5194/gmd3-43-2010, 2010.

FAO: Global Forest Resources Assessment 2010, Rome, 2010.

Feddema, J. J., Oleson, K. W., Bonan, G. B., Mearns, L. O., Buja, L. E., Meehl, G. A., and Washington, W. M.: The importance of land-cover change in simulating future climates, Science, 310, 1674-1678, doi:10.1126/science.1118160, 2005. 
Foley, J. A., Defries, R., Asner, G. P., Barford, C., Bonan, G., Carpenter, S. R., Chapin, F. S., Coe, M. T., Daily, G. C., Gibbs, H. K., Helkowski, J. H., Holloway, T., Howard, E. A., Kucharik, C. J., Monfreda, C., Patz, J. A., Prentice, I. C., Ramankutty, N., and Snyder, P. K.: Global consequences of land use, Science, 309, 570-574, doi:10.1126/science.1111772, 2005.

Foley, J. A., Ramankutty, N., Brauman, K. A., Cassidy, E. S., Gerber, J. S., Johnston, M., Mueller, N. D., O/'Connell, C., Ray, D. K., West, P. C., Balzer, C., Bennett, E. M., Carpenter, S. R., Hill, J., Monfreda, C., Polasky, S., Rockstrom, J., Sheehan, J., Siebert, S., Tilman, D., and Zaks, D. P. M.: Solutions for a cultivated planet, Nature, 478, 337-342, 2011.

Forster, P., Ramaswamy, V., Artaxo, P., Berntsen, T., Betts, R., Fahey, D. W., Haywood, J., Lean, J., Lowe, D. C., Myhre, G., Nganga, J., Prinn, R., Raga, G., Schulz, M., and Dorland, R. V.: Changes in Atmospheric Constituents and in Radiative Forcing, in: Climate Change 2007: The Physical Science Basis, Contribution of Working Group I to the Fourth Assessment Report of the Intergovernmental Panel on Climate Change, edited by: Solomon, S., Qin, D., Manning, M., Chen, Z., Marquis, M., Averyt, K. B., Tignor, M., and Miller, H. L., Cambridge University Press, New York City, NY, USA, 129-234, 2007.

Fujino, J., Nair, R., Kainuma, M., Masui, T., and Matsuoka, Y.: Multi-gas Mitigation Analysis on Stabilization Scenarios Using Aim Global Model, Energy J., 27, 343-353, 2006.

Ganzeveld, L., Bouwman, L., Stehfest, E., van Vuuren, D. P., Eickhout, B., and Lelieveld, J.: Impact of future land use and land cover changes on atmospheric chemistry-climate interactions, J. Geophys. Res., 115, D23301, doi:10.1029/2010jd014041, 2010.

Gent, P. R., Danabasoglu, G., Donner, L. J., Holland, M. M., Hunke, E. C., Jayne, S. R., Lawrence, D. M., Neale, R. B., Rasch, P. J., Vertenstein, M., Worley, P. H., Yang, Z.-L., and Zhang, M.: The Community Climate System Model Version 4, J. Climate, 24, 4973-4991, doi:10.1175/2011JCLI4083.1, 2011.

Ginoux, P., Prospero, J. M., Gill, T. E., Hsu, N. C., and Zhao, M.: Global-scale attribution of anthropogenic and natural dust sources and their emission rates based on MODIS Deep Blue aerosol products, Rev. Geophys., 50, RG3005, doi:10.1029/2012RG000388, 2012.

Godfray, H. C., Beddington, J. R., Crute, I. R., Haddad, L., Lawrence, D., Muir, J. F., Pretty, J., Robinson, S., Thomas, S. M., and Toulmin, C.: Food security: the challenge of feeding 9 billion people, Science, 327, 812-818, doi:10.1126/science.1185383, 2010

Hansen, J., Sato, M., Ruedy, R., Nazarenko, L., Lacis, A., Schmidt, G. A., Russell, G., Aleinov, I., Bauer, M., Bauer, S., Bell, N., Cairns, B., Canuto, V., Chandler, M., Cheng, Y., Del Genio, A., Faluvegi, G., Fleming, E., Friend, A., Hall, T., Jackman, C., Kelley, M., Kiang, N., Koch, D., Lean, J., Lerner, J., Lo, K., Menon, S., Miller, R., Minnis, P., Novakov, T., Oinas, V., Perlwitz, J., Perlwitz, J., Rind, D., Romanou, A., Shindell, D., Stone, P., Sun, S., Tausnev, N., Thresher, D., Wielicki, B., Wong, T., Yao, M., and Zhang, S.: Efficacy of climate forcings, J. Geophys. Res.Atmos., 110, D18104, doi:10.1029/2005JD005776, 2005.

Hansen, M. C., Potapov, P. V., Moore, R., Hancher, M., Turubanova, S. A., Tyukavina, A., Thau, D., Stehman, S. V., Goetz, S. J., Loveland, T. R., Kommareddy, A., Egorov, A., Chini, L., Justice, C. O., and Townshend, J. R.: High-resolution global maps of 21st-century forest cover change, Science, 342, 850-853, doi:10.1126/science.1244693, 2013.

Harrison, S. P., Marlon, J. R., and Bartlein, P. J.: Fire in the earth system. Changing Climates, Earth Systems and Society, International Year of Planet Earth, Dodson, J., Springer, New York, USA, 2010.

Heald, C. L., Henze, D. K., Horowitz, L. W., Feddema, J., Lamarque, J. F., Guenther, A., Hess, P. G., Vitt, F., Seinfeld, J. H., Goldstein, A. H., and Fung, I.: Predicted change in global secondary organic aerosol concentrations in response to future climate, emissions, and land use change, J. Geophys. Res., 113, D05211, doi:10.1029/2007jd009092, 2008.

Houghton, R. A.: Carbon emissions and the drivers of deforestation and forest degradation in the tropics, Curr. Opin. Environ. Sustain., 4, 597-603, doi:10.1016/j.cosust.2012.06.006, 2012.

Houghton, R. A., Hackler, J. L., and Lawrence, K. T.: The U.S. Carbon Budget: Contributions from Land-Use Change, Science, 285, 574-578, doi:10.1126/science.285.5427.574, 1999.

Hurrell, J. W., Holland, M. M., Gent, P. R., Ghan, S., Kay, J. E., Kushner, P. J., Lamarque, J. F., Large, W. G., Lawrence, D., Lindsay, K., Lipscomb, W. H., Long, M. C., Mahowald, N., Marsh, D. R., Neale, R. B., Rasch, P., Vavrus, S., Vertenstein, M., Bader, D., Collins, W. D., Hack, J. J., Kiehl, J., and Marshall, S.: The Community Earth System Model: A Framework for Collaborative Research, B. Am. Meteorol. Soc., 94, 13391360, doi:10.1175/BAMS-D-12-00121.1, 2013.

Hurtt, G. C., Chini, L. P., Frolking, S., Betts, R. A., Feddema, J., Fischer, G., Fisk, J. P., Hibbard, K., Houghton, R. A., Janetos, A., Jones, C. D., Kindermann, G., Kinoshita, T., Klein Goldewijk, K., Riahi, K., Shevliakova, E., Smith, S., Stehfest, E., Thomson, A., Thornton, P., Vuuren, D. P., and Wang, Y. P.: Harmonization of land-use scenarios for the period 1500-2100: 600 years of global gridded annual land-use transitions, wood harvest, and resulting secondary lands, Climatic Change, 109, 117-161, doi:10.1007/s10584-011-0153-2, 2011.

Jones, A. D., Collins, W. D., and Torn, M. S.: On the additivity of radiative forcing between land use change and greenhouse gases, Geophys. Res. Lett., 40, 4036-4041, doi:10.1002/grl.50754, 2013.

Kim, D.-H., Sexton, J. O., and Townshend, J. R.: Accelerated deforestation in the humid tropics from the 1990s to the 2000s, Geophys. Res. Lett., doi:10.1002/2014GL062777, in press, 2015.

Kloster, S., Mahowald, N. M., Randerson, J. T., Thornton, P. E., Hoffman, F. M., Levis, S., Lawrence, P. J., Feddema, J. J., Oleson, K. W., and Lawrence, D. M.: Fire dynamics during the 20th century simulated by the Community Land Model, Biogeosciences, 7, 1877-1902, doi:10.5194/bg-7-1877-2010, 2010.

Kloster, S., Mahowald, N. M., Randerson, J. T., and Lawrence, P. J.: The impacts of climate, land use, and demography on fires during the 21 st century simulated by CLM-CN, Biogeosciences, 9, 509-525, doi:10.5194/bg-9-509-2012, 2012.

Kroeze, C., Mosier, A., and Bouwman, L.: Closing the global N2O budget: A retrospective analysis 1500-1994, Global Biogeochem. Cy., 13, 1-8, 1999.

Lal, R.: Soil carbon sequestration impacts on global climate change and food security, Science, 304, 1623-1627, doi:10.1126/science.1097396, 2004.

Lamarque, J. F., Bond, T. C., Eyring, V., Granier, C., Heil, A., Klimont, Z., Lee, D., Liousse, C., Mieville, A., Owen, B., 
Schultz, M. G., Shindell, D., Smith, S. J., Stehfest, E., Van Aardenne, J., Cooper, O. R., Kainuma, M., Mahowald, N., McConnell, J. R., Naik, V., Riahi, K., and van Vuuren, D. P.: Historical (1850-2000) gridded anthropogenic and biomass burning emissions of reactive gases and aerosols: methodology and application, Atmos. Chem. Phys., 10, 7017-7039, doi:10.5194/acp10-7017-2010, 2010.

Lawrence, P. J. and Chase, T. N.: Investigating the climate impacts of global land cover change in the community climate system model, Int. J. Climatol., 30, 2066-2087, doi:10.1002/joc.2061, 2010.

Lawrence, P. J., Feddema, J. J., Bonan, G. B., Meehl, G. A., O’Neill, B. C., Oleson, K. W., Levis, S., Lawrence, D. M., Kluzek, E., Lindsay, K., and Thornton, P. E.: Simulating the Biogeochemical and Biogeophysical Impacts of Transient Land Cover Change and Wood Harvest in the Community Climate System Model (CCSM4) from 1850 to 2100, J. Climate, 25, 3071-3095, doi:10.1175/jcli-d-11-00256.1, 2012.

Lehner, B. and Doll, P.: Development and validation of a global database of lakes resevoirs and wetlands, J. Hydrol., 296, 1-22, 2004.

Liu, X., Easter, R. C., Ghan, S. J., Zaveri, R., Rasch, P., Shi, X., Lamarque, J. F., Gettelman, A., Morrison, H., Vitt, F., Conley, A., Park, S., Neale, R., Hannay, C., Ekman, A. M. L., Hess, P., Mahowald, N., Collins, W., Iacono, M. J., Bretherton, C. S., Flanner, M. G., and Mitchell, D.: Toward a minimal representation of aerosols in climate models: description and evaluation in the Community Atmosphere Model CAM5, Geosci. Model Dev., 5, 709-739, doi:10.5194/gmd-5-709-2012, 2012.

Lubowski, R. N. and Rose, S. K.: The Potential for REDD+: Key Economic Modeling Insights and Issues, Rev. Environ. Econ. Policy, 7, 67-90, doi:10.1093/reep/res024, 2013.

Mahowald, N.: Aerosol indirect effect on biogeochemical cycles and climate, Science, 334, 794-796, doi:10.1126/science.1207374, 2011.

Margono, B. A., Potapov, P. V., Turubanova, S., Stolle, F., and Hansen, M. C.: Primary forest cover loss in Indonesia over 2000-2012, Nat. Clim. Change, 4, 730-735, doi:10.1038/nclimate2277, 2014.

Marlon, J. R., Bartlein, P. J., Carcaillet, C., Gavin, D. G., Harrison, S. P., Higuera, P. E., Joos, F., Power, M. J., and Prentice, I. C.: Climate and human influences on global biomass burning over the past two millennia, Nat. Geosci., 1, 697-702, doi:10.1038/ngeo313, 2008.

Matthews, H. D., Weaver, A. J., Meissner, K. J., Gillett, N. P., and Eby, M.: Natural and anthropogenic climate change: incorporating historical land cover change, vegetation dynamics and the global carbon cycle, Clim. Dynam., 22, 461-479, doi:10.1007/s00382-004-0392-2, 2004.

Matthews, H. D., Graham, T. L., Keverian, S., Lamontagne, C., Seto, D., and Smith, T. J.: National contributions to observed global warming, Environ. Res. Lett., 9, 014010, doi:10.1088/1748-9326/9/1/014010, 2014.

Meinshausen, M., Raper, S. C. B., and Wigley, T. M. L.: Emulating coupled atmosphere-ocean and carbon cycle models with a simpler model, MAGICC6 - Part 1: Model description and calibration, Atmos. Chem. Phys., 11, 1417-1456, doi:10.5194/acp11-1417-2011, 2011.
Mendelsohn, R. and Dinar, A.: Land Use and Climate Change Interactions, Annu. Rev. Resour. Econ., 1, 309-332, doi:10.1146/annurev.resource.050708.144246, 2009.

Molen, M. K., Hurk, B. J. J. M., and Hazeleger, W.: A dampened land use change climate response towards the tropics, Clim. Dynam., 37, 2035-2043, doi:10.1007/s00382-011-1018-0, 2011.

Moore, S., Evans, C. D., Page, S. E., Garnett, M. H., Jones, T. G., Freeman, C., Hooijer, A., Wiltshire, A. J., Limin, S. H., and Gauci, V.: Deep instability of deforested tropical peatlands revealed by fluvial organic carbon fluxes, Nature, 493, 660-663, 2013.

Moss, R. H., Edmonds, J. A., Hibbard, K. A., Manning, M. R., Rose, S. K., van Vuuren, D. P., Carter, T. R., Emori, S., Kainuma, M., Kram, T., Meehl, G. A., Mitchell, J. F., Nakicenovic, N., Riahi, K., Smith, S. J., Stouffer, R. J., Thomson, A. M., Weyant, J. P., and Wilbanks, T. J.: The next generation of scenarios for climate change research and assessment, Nature, 463, 747-756, doi:10.1038/nature08823, 2010.

Myhre, G., Shindell, D., Breon, F.-M., Collins, W., Fuglestvedt, J., Huang, J., Koch, D., Lamarque, J. F., Lee, D., Mendoza, B., Nakajima, T., Robock, A., Stephens, G., Takemura, T., and Zhang, H.: Anthropogenic and Natural Radiative Forcing, in: Climate Change 2013: The Physical Science Basis, Contribution of Working Group I to the Fifth Assessment Report of the Intergovernmental Panel on Climate Change, edited by: Stocker, T. F., Qin, D., Plattner, G.-K., Tignor, M., Allen, S. K., Boschung, J., Nauels, A., Xia, Y., Bex, V., and Midgley, P. M., Cambridge University Press, New York, NY, USA, 659-740, 2013.

Naik, V., Mauzerall, D., Horowitz, L., Schwarzkopf, M. D., Ramaswamy, V., and Oppenheimer, M.: Net radiative forcing due to changes in regional emissions of tropospheric ozone precursors, J. Geophys. Res., 110, D24306, doi:10.1029/2005jd005908, 2005.

Nepstad, D. C., Verssimo, A., Alencar, A., Nobre, C., Lima, E., Lefebvre, P., Schlesinger, P., Potter, C., Moutinho, P., Mendoza, E., Cochrane, M., and Brooks, V.: Large-scale impoverishment of Amazonian forests by logging and fire, Nature, 398, 505-508, 1999.

Nepstad, D. C., Schwartzman, S., Bamberger, B., Santilli, M., Ray, D., Schlesinger, P., Lefebvre, P., Alencar, A., Prinz, E., Fiske, G., and Rolla, A.: Inhibition of Amazon Deforestation and Fire by Parks and Indigenous Lands, Conserv. Biol., 20, 65-73, doi:10.1111/j.1523-1739.2006.00351.x, 2006.

O’Halloran, T. L., Law, B. E., Goulden, M. L., Wang, Z., Barr, J. G., Schaaf, C., Brown, M., Fuentes, J. D., Göckede, M., Black, A., and Engel, V.: Radiative forcing of natural forest disturbances, Global Change Biol., 18, 555-565, doi:10.1111/j.13652486.2011.02577.x, 2011.

Oleson, K. W., Niu, G. Y., Yang, Z. L., Lawrence, D. M., Thornton, P. E., Lawrence, P. J., Stöckli, R., Dickinson, R. E., Bonan, G. B., Levis, S., Dai, A., and Qian, T.: Improvements to the Community Land Model and their impact on the hydrological cycle, J. Geophys. Res., 113, G01021, doi:10.1029/2007jg000563, 2008.

Pechony, O. and Shindell, D. T.: Driving forces of global wildfires over the past millennium and the forthcoming century, P. Natl. Acad. Sci. USA, 107, 19167-19170, doi:10.1073/pnas.1003669107, 2010.

Pielke, R. A., Marland, G., Betts, R. A., Chase, T. N., Eastman, J. L., Niles, J. O., Niyogi, D. S., and Running, S. W.: The influence of 
land-use change and landscape dynamics on the climate system: relevance to climate-change policy beyond the radiative effect of greenhouse gases, Philis. T. Roy. Soc. A, 360, 1705-1719, 2002.

Pongratz, J. and Caldeira, K.: Attribution of atmospheric $\mathrm{CO}_{2}$ and temperature increases to regions: importance of preindustrial land use change, Environ. Res. Lett., 7, 034001, doi:10.1088/1748-9326/7/3/034001, 2012.

Pongratz, J., Reick, C., Raddatz, T., and Claussen, M.: A reconstruction of global agricultural areas and land cover for the last millennium, Global Biogeochem. Cy., 22, GB3018, doi:10.1029/2007gb003153, 2008 .

Pongratz, J., Reick, C. H., Houghton, R. A., and House, J. I.: Terminology as a key uncertainty in net land use and land cover change carbon flux estimates, Earth Syst. Dynam., 5, 177-195, doi:10.5194/esd-5-177-2014, 2014.

Prather, M., Ehhalt, D., Dentener, F., Derwent, R., Dlugokencky, E. J., Holland, E., Isaksen, I., Katima, J., Kirchhoff, V., Matson, P., Midgley, P., and Wang, M.: Atmospheric Chemistry and Greenhouse Gases, in: Climate Change 2001: The Scientific Basis, edited by: Houghton, J. T., Ding, Y., Griggs, D. J., Noguer, M., Van der Linden, P. J., Dai, X., Maskell, K., and Johnson, C. A., Intergovernmental Panel on Climate Change, Cambridge University Press, Cambridge, 239-287, 2001.

Prentice, I. C., Kelley, D. I., Foster, P. N., Friedlingstein, P., Harrison, S. P., and Bartlein, P. J.: Modeling fire and the terrestrial carbon balance, Global Biogeochem. Cy., 25, GB3005, doi:10.1029/2010gb003906, 2011.

Qian, T., Dai, A., Trenberth, K. E., and Oleson, K. W.: Simulation of global land surface conditions from 1948 to 2004, Part I: Forcing data and evaluations, J. Hydrometeorol., 7, 953-975, 2006.

Ramaswamy, V., Boucher, O., Haigh, J., Hauglustine, D., Haywood, J., Myhre, G., Nakajima, T., Shi, G., and Solomon, S.: Radiative forcing of climate, in: Climate Change 2001: The Scientific Basis, edited by: Houghton, J. T., Ding, Y., Griggs, D. J., Noguer, M., Van der Linden, P. J., Dai, X., Maskell, K., and Johnson, C. A., Intergovernmental Panel on Climate Change, Cambridge University Press, Cambridge, UK, 349-416, 2001.

Randerson, J. T., Liu, H., Flanner, M. G., Chambers, S. D., Jin, Y., Hess, P. G., Pfister, G., Mack, M. C., Treseder, K. K., Welp, L. R., Chapin, F. S., Harden, J. W., Goulden, M. L., Lyons, E., Neff, J. C., Schuur, E. A., and Zender, C. S.: The impact of boreal forest fire on climate warming, Science, 314, 1130-1132, doi:10.1126/science.1132075, 2006 .

Reisinger, A. and Ledgard, S.: Impact of greenhouse gas metrics on the quantification of agricultural emissions and farm-scale mitigation strategies: a New Zealand case study, Environ. Res. Lett., 8, 025019, doi:10.1088/1748-9326/8/2/025019, 2013.

Riahi, K., Grübler, A., and Nakicenovic, N.: Scenarios of long-term socio-economic and environmental development under climate stabilization, Technol. Forecast. Social Change, 74, 887-935, doi:10.1016/j.techfore.2006.05.026, 2007.

Runyan, C. W., D’Odorico, P., and Lawrence, D.: Physical and biological feedbacks of deforestation, Rev. Geophys., 50, RG4006, doi:10.1029/2012rg000394, 2012.

Shindell, D. T., Faluvegi, G., Koch, D. M., Schmidt, G. A., Unger, N., and Bauer, S. E.: Improved attribution of climate forcing to emissions, Science, 326, 716-718, doi:10.1126/science. $1174760,2009$.
Strassmann, K. M., Joos, F., and Fischer, G.: Simulating effects of land use changes on carbon fluxes: past contributions to atmospheric $\mathrm{CO}_{2}$ increases and future commitments due to losses of terrestrial sink capacity, Tellus B, 60, 583-603, doi:10.1111/j.1600-0889.2008.00340.x, 2008.

Streets, D. G., Shindell, D. T., Lu, Z., and Faluvegi, G.: Radiative forcing due to major aerosol emitting sectors in China and India, Geophys. Res. Lett., 40, 4409-4414, doi:10.1002/grl.50805, 2013.

Taylor, K. E., Stouffer, R. J., and Meehl, G. A.: An Overview of CMIP5 and the Experiment Design, B. Am. Meteorol. Soc., 93, 485-498, doi:10.1175/bams-d-11-00094.1, 2012.

Thornton, P. E., Doney, S. C., Lindsay, K., Moore, J. K., Mahowald, N., Randerson, J. T., Fung, I., Lamarque, J. F., Feddema, J. J., and Lee, Y. H.: Carbon-nitrogen interactions regulate climate-carbon cycle feedbacks: results from an atmosphere-ocean general circulation model, Biogeosciences, 6, 2099-2120, doi:10.5194/bg6-2099-2009, 2009.

Unger, N.: Human land-use-driven reduction of forest volatiles cools global climate, Nat. Clim. Change, 4, 907-911, doi:10.1038/NCLIMATE2347, 2014.

Unger, N., Bond, T. C., Wang, J. S., Koch, D. M., Menon, S., Shindell, D. T., and Bauer, S.: Attribution of climate forcing to economic sectors, P. Natl. Acad. Sci. USA, 107, 3382-3387, doi:10.1073/pnas.0906548107, 2010.

van der Werf, E. and Peterson, S.: Modeling linkages between climate policy and land use: an overview, Agr. Econ., 40, 507-517, doi:10.1111/j.1574-0862.2009.00394.x, 2009.

Vuuren, D. P., Elzen, M. G. J., Lucas, P. L., Eickhout, B., Strengers, B. J., Ruijven, B., Wonink, S., and Houdt, R.: Stabilizing greenhouse gas concentrations at low levels: an assessment of reduction strategies and costs, Climatic Change, 81, 119-159, doi:10.1007/s10584-006-9172-9, 2007.

Vuuren, D. P., Edmonds, J., Kainuma, M., Riahi, K., Thomson, A., Hibbard, K., Hurtt, G. C., Kram, T., Krey, V., Lamarque, J.F., Masui, T., Meinshausen, M., Nakicenovic, N., Smith, S. J., and Rose, S. K.: The representative concentration pathways: an overview, Climatic Change, 109, 5-31, doi:10.1007/s10584-0110148-z, 2011.

Ward, D. S. and Mahowald, N. M.: Contributions of developed and developing countries to global climate forcing and surface temperature change, Environ. Res. Lett., 9, 074008, doi:10.1088/1748-9326/9/7/074008, 2014.

Ward, D. S., Kloster, S., Mahowald, N. M., Rogers, B. M., Randerson, J. T., and Hess, P. G.: The changing radiative forcing of fires: global model estimates for past, present and future, Atmos. Chem. Phys., 12, 10857-10886, doi:10.5194/acp12-10857-2012, 2012.

Ward, D. S., Mahowald, N. M., and Kloster, S.: Potential climate forcing of land use and land cover change, Atmos. Chem. Phys., 14, 12701-12724, doi:10.5194/acp-14-12701-2014, 2014.

Wise, M., Calvin, K., Thomson, A., Clarke, L., Bond-Lamberty, B., Sands, R., Smith, S. J., Janetos, A., and Edmonds, J.: Implications of limiting $\mathrm{CO}_{2}$ concentrations for land use and energy, Science, 324, 1183-1186, doi:10.1126/science.1168475, 2009.

Yang, J., Tian, H., Tao, B., Ren, W., Kush, J., Liu, Y., and Wang, Y.: Spatial and temporal patterns of global burned area in response to anthropogenic and environmental factors: Reconstructing global 
fire history for the 20th and early 21st centuries, J. Geophys. Res.-Biogeo., 119, 249-263, doi:10.1002/2013jg002532, 2014.
Zaehle, S., Ciais, P., Friend, A. D., and Prieur, V.: Carbon benefits of anthropogenic reactive nitrogen offset by nitrous oxide emissions, Nat. Geosci., 4, 601-605, 2011. 